Article

\title{
Scenarios for the Development of Multimodal Transport in the TRITIA Cross-Border Area
}

\author{
Marzena Kramarz, Katarzyna Dohn* * Edyta Przybylska® and Lilla Knop® \\ Faculty of Organization and Management, Silesian University of Technology, Roosevelt 32 Str., 41-800 Zabrze, \\ Poland; marzena.kramarz@polsl.pl (M.K.); edyta.przybylska@polsl.pl (E.P.); lilla.knop@polsl.pl (L.K.) \\ * Correspondence: katarzyna.dohn@polsl.pl; Tel.: +48-32-277-7339
}

Received: 23 July 2020; Accepted: 25 August 2020; Published: 28 August 2020

\begin{abstract}
As the demand for transport is growing, more and more attention is being paid to its quality aspects. These include, among other things, efficiency, safety, and a continuous effort to reduce external costs. That is why the transport policies of the EU countries and individual regions are increasingly addressing the issue of sustainable transport development. Multimodal transport, which is seen as a key element to effectively counterbalance the dominant role of vehicle transport in the economic progress of the European Community, plays an important role in these programmes. For consistency and continuity of freight flows, cooperation between neighbouring countries and regions is essential. The future of multimodal freight transport within the cross-border area of Poland, Czech Republic and Slovakia is not as evident as the transport policies imply. Therefore, the purpose of the paper is to identify a set of factors determining the development of multimodal transport within the cross-border area of TRITIA (The European Grouping of Territorial Cooperation of the four regional governments of Moravian-Silesian Region (CZ), Opole Voivodeship (PL), Silesian Voivodeship (PL) and Žilina Self-governing Region (SK)) and to develop four scenarios, the execution of which in the 2030 perspective depends on the implementation of cross-border infrastructure and organisational projects and the increasing level of cooperation in the field of multimodal transport. The article contains the methodology for developing scenarios of multimodal freight transport development. The research showed that initiating activities targeted at the development of multimodal transport within the cross-border area requires the involvement of all participants in the process, i.e., all countries (Poland, Czech Republic and Slovakia), along with many different stakeholders. The future development of multimodal transport as provided for in the scenarios is not linearly correlated with the increase in cooperation and the number of implemented infrastructure and organisational projects. It is vital for future research to define the role of stakeholders both in terms of cooperation and collaboration development.
\end{abstract}

Keywords: multimodal transport; scenario analysis; TRITIA area

\section{Introduction}

One of the most essential tasks in the implementation of the sustainable development policy of the Central and Eastern European countries is to equalise with the Western European countries in terms of the level of civilizational development and living standards. This requires, however, the creation of solid structural foundations for economic growth, including an efficient transport system. It is also a crucial task from the point of view of taking actions for the development of cross-border areas, where problems and their scale extend significantly beyond the borders of the regions of the neighbouring countries [1]. It is worth mentioning that the cross-border cooperation plays an important and significant role in the process of integration of European territories [2-5]. Considering the specific location of border regions, they are often excluded from large national 
infrastructure investments because of their peripheral location, natural and anthropogenic barriers, etc., which undoubtedly impedes cross-border integration [6]. Furthermore, many authors point out that cross-border interactions hardly ever result in thorough integration, and that the border remains a strong dividing line [4,7-11]. Nevertheless, these areas benefit from the exceptional support of the European Union in creating conditions for equal development opportunities for economically or socially disadvantaged areas.

The cross-border area covering three countries: Poland, Czech Republic and Slovakia is particularly significant due to its location, establishing for instance the infrastructure of the Baltic-Adriatic Core Network Corridor (as defined in Regulations (EU) 1315/2013 [12] and 1316/2013 [13]) TEN-T Regulation (EU) 1315/2013 [12] in its Article 4 and 10 defines the general objectives and priorities for the development of the core network corridors, which include cohesive development objectives such as ensuring greater accessibility and reducing the differences in infrastructure quality between Member States, developing long-distance connections, regional and local traffic and optimal integration of the different transport modes, efficiency objectives such as completing missing links and removing bottlenecks, especially on cross-border sections, promoting interoperability between different transport modes, supporting the efficient and sustainable use of infrastructure and, where necessary, increasing capacity [14]. This represents a relatively good basis for the development of international multimodal sustainable transport, also bearing in mind the goals set in the White Paper for long-distance freight transport (by $2030,30 \%$ of road freight transport over $300 \mathrm{~km}$ should be shifted to rail or water transport, and by 2050 it should account for over $50 \%$ of this type of transport) [15]. However, it should be observed critically that rail transport within the cross-border area in question is still largely formed by traditional market segments with low added value goods (coal and energy products, ores, metals and construction materials). The development of competitive combined transport services for processed products is therefore of great importance in order to maintain or increase the share of rail transport within the medium- and long-term perspective [14]. This clearly illustrates the growing potential of multimodal transport. For further growth, however, it is necessary to adapt proper legal regulations supporting this technology, develop an appropriate number of highly efficient multimodal transport terminals equipped with suprastructure, determine relevant prices for access to terminals, terminal operation prices and prices for access to linear infrastructure [16]. This necessitates huge investment expenditures, but first and foremost, an active role of the states in terms of their transport policy and the possibility of administrative support for the development of infrastructure required for the implementation of multimodal transport. Nevertheless, the international policy so far, often of a very general nature, has not always been effective in improving the competitive position of multimodal transport, as it has not usually included all the entities involved in the transport services supply chain [17]. It is important to emphasise that the creation of an efficient and coherent cross-border transport network is an issue which is still relevant, as there is no proposal for a systemic approach to this problem. The promotion of the role of multimodal transport has not brought the desired results [18], and therefore it becomes necessary to conduct research on the development of transport systems in an international perspective, including solutions to many problems corresponding to individual investments, changing the transport infrastructure, but also solving organisational problems of transport activity. The authors of this publication, conducting research in this field, found it justified to take actions towards defining scenarios for development of multimodal transport within the cross-border area of Poland-Czech Republic-Slovakia. The literature on freight transport development scenarios mainly refers to either the development of single modes of transport (mostly road transport) [19,20], or analyses conducted in relation to national transport systems [21,22]. In this paper, an attempt is made to develop scenarios aimed at the development of multimodal transport and its implementation within the cross-border area in the 2030 perspective.

The main objective of the paper, following the defined cause-and-effect relations in the multimodal transport network, is to identify a set of factors determining the development of multimodal transport within the cross-border area and to prepare four scenarios, the implementation of which in the 2030 
perspective depends on the implementation of cross-border infrastructure and organisational projects, contributing to the increase in cooperation in the field of multimodal transport.

The following research questions were formed within the research process adopted in the article:

1. What factors have the greatest impact on the development of multimodal transport within the cross-border area Poland-Czech Republic-Slovakia in the 2030 perspective?

2. What are the prospects for the development of multimodal transport in the TRITIA cross-border area in 2030 and how do they depend on cooperation and joint undertakings?

3. What trends in key factors describe the presented prospects for the development of multimodal transport in the area of TRITIA and what is the probability of the particular scenarios emerging in the 2030 perspective?

4. Which group of projects is required to be implemented when a specific scenario occurs?

The article presents the method of building scenarios for the development of multimodal transport within the cross-border area, supported by qualitative research, including mainly expert studies, trend analysis and the analysis of strategic documents. Currently, there are no developed multimodal transport strategies included in the policy of specific countries, specific regions and entire TRITIA cross-border area. The article is the result of works conducted within the TRANS TRITIA project. One of the most important elements of the project is the elaboration of the strategy and action plans of multimodal freight transport realised in the monitored regions. Developed scenarios should become the basis for indicating the strategic priorities and developing the goals and methods of their implementation. Presented results can be used by both local government of specific cross-border regions and national government aiming to develop strategies of the multimodal transport development.

\section{Theoretical Background}

\subsection{Multimodal Freight Transport within the Cross-Border Areas}

One of the primary objectives of the functioning of the international communities is not only the economic but also social and territorial cohesion of the Member States. Such communities aim both at reducing barriers resulting from internal borders and at deepening integration within the community. In order to strengthen territorial cohesion, it is necessary to connect individual Member States through efficient cross-border transport infrastructure and services.

The first years of 2000 in Europe characterised with a downward trend in average expenditures on infrastructure. However, the economic and financial crisis has restored the interest in infrastructure investment needs. During the economic crisis, investments aimed at modernising or building infrastructure have become an important part of stimulus and recovery plans at EU and Member State level as a way to facilitate demand aggregation while ensuring a long-term return on investment. More importantly, the crisis has shown the crucial importance of infrastructure for Europe's economic future [23].

Currently, despite a significant number of investments undertaken, the European Union does not have a sufficiently interconnected, interoperable and resource-efficient cross-border transport infrastructure network [23]. Clearly this, in addition to linguistic differences, national regulations and policies that divide neighbouring territories [24], is a key barrier to the desired European territorial integration. The common European transport system is therefore regarded as very important for the EU territory. However, although ambitious objectives have been formulated and efforts have been made to contribute to an efficient internal transport system in Europe, bottlenecks and inefficient networked transport services at the borders are still a serious problem in many parts of the EU territory.

An essential element of the EU's transport infrastructure policy to transform the existing patchwork of European roads, railways, inland waterways, airports, inland and seaports and rail/road terminals, was the development of an integrated network covering all Member States-TEN-T. In this regard, for the first time, a two-level structure for the EU transport routes was introduced, comprising a 
comprehensive network (ensuring effective connections to all the EU regions) and a core network (covering the strategically most significant elements of the comprehensive network) [25].

The development of international trade implies a strong increase in freight transport on a local, regional, national, international and global scale. This situation raises a whole range of problems and challenges related to the organisation of the flow of goods, especially taking into consideration the assumptions of transport policy, which is a part of the concept of sustainable development, reduction of external costs of transport and environmental protection. Within this context, attention should also be paid to cross-border areas, which are strongly involved in the undertaken transport processes. These are areas on both sides of the border lines that, on the one hand, play an essential role in social and economic life and, on the other, require strong cooperation, integration and the overcoming of the existing barriers. Such activities are also required by transport, including freight transport, which also, within the cross-border areas, should fulfil the assumed mission and objectives of the White Paper [15].

As mentioned earlier, European integration necessitates the implementation of an increasing number of solutions related to the cross-border freight transport problems. The key issue in this respect is the compatibility of the national and regional solutions. It is very important to collect relevant and comparable data on the demand for cross-border traffic and a certain level of standardisation of studies and their methodology for determining demand for such transport. Apart from this type of information, cooperation and discussions between institutions and other entities involved in the flows concerned are particularly relevant [26]. As I. Semenov [27] observes, the level of compatibility of transport and logistics systems involved within the cross-border transport directly impacts transport costs, the quality of logistics services provided, security and timeliness of deliveries, and consequently, the level of efficiency and profitability of the entire logistics chain. Regarding cross-border transport, the multimodality of transport should also be developed, but it is advisable to be aware of the desire to improve the consistency of individual solutions, including both mono and inter-branch.

The execution of transport processes within the cross-border areas belongs to the international transport matters despite the fact that some of these processes involve relatively short distances. The international transport models that are being built must recognise the differences resulting from the differences in the areas located on both sides of the border. These include differences related to seasonality of supply and demand for goods, demographic parameters, economic development, level of innovation, level of technological development, and resource needs [28]. All these factors influence the implementation of freight flows between different countries. Based on this, H. Meersmen et al. [28], point out the micro and macro approach to building transport models in the context of international flows. The first so-called "micro approach" is to combine different national transport models in order to fulfil a transport task. The second so-called "macro approach" is based on creating a general international model without breaking it down into national models. The main advantage of this approach is the use of a uniform set of parameters and structures, which enables full compatibility of the systems. The latter approach seems to be particularly relevant within the cross-border areas.

The development of multimodal transport, also within the cross-border areas, is often impeded by a number of barriers, which take on a variety of different forms (technical, organisational, or legislative). These barriers (Figure 1), which constitute a kind of bottleneck for development, need to be eliminated or at least mitigated. This is mainly due to the standardisation and integration in transport markets, both in terms of legal requirements and the application of similar principles of transport organisation and technology [29]. Considering the examples of existing barriers, their elimination should concern, in particular [27]:

- the standardisation of technical norms for multimodal transport infrastructure,

- compatibility of various branches of transport,

- compatibility of tax regulations,

- the application of the principles of free competition,

- combating discrimination against carriers with regard to their place of establishment,

- the use of standardised ITS solutions. 
The overcoming of these barriers is a difficult task and requires the involvement of many stakeholders of the entire cross-border area. It should be assumed that in order to eliminate or mitigate these barriers it is necessary, on the one hand, to generate and implement a number of projects of an infrastructural, technological and organisational nature, and on the other hand, to cooperate with various entities engaged in the development of multimodal transport.

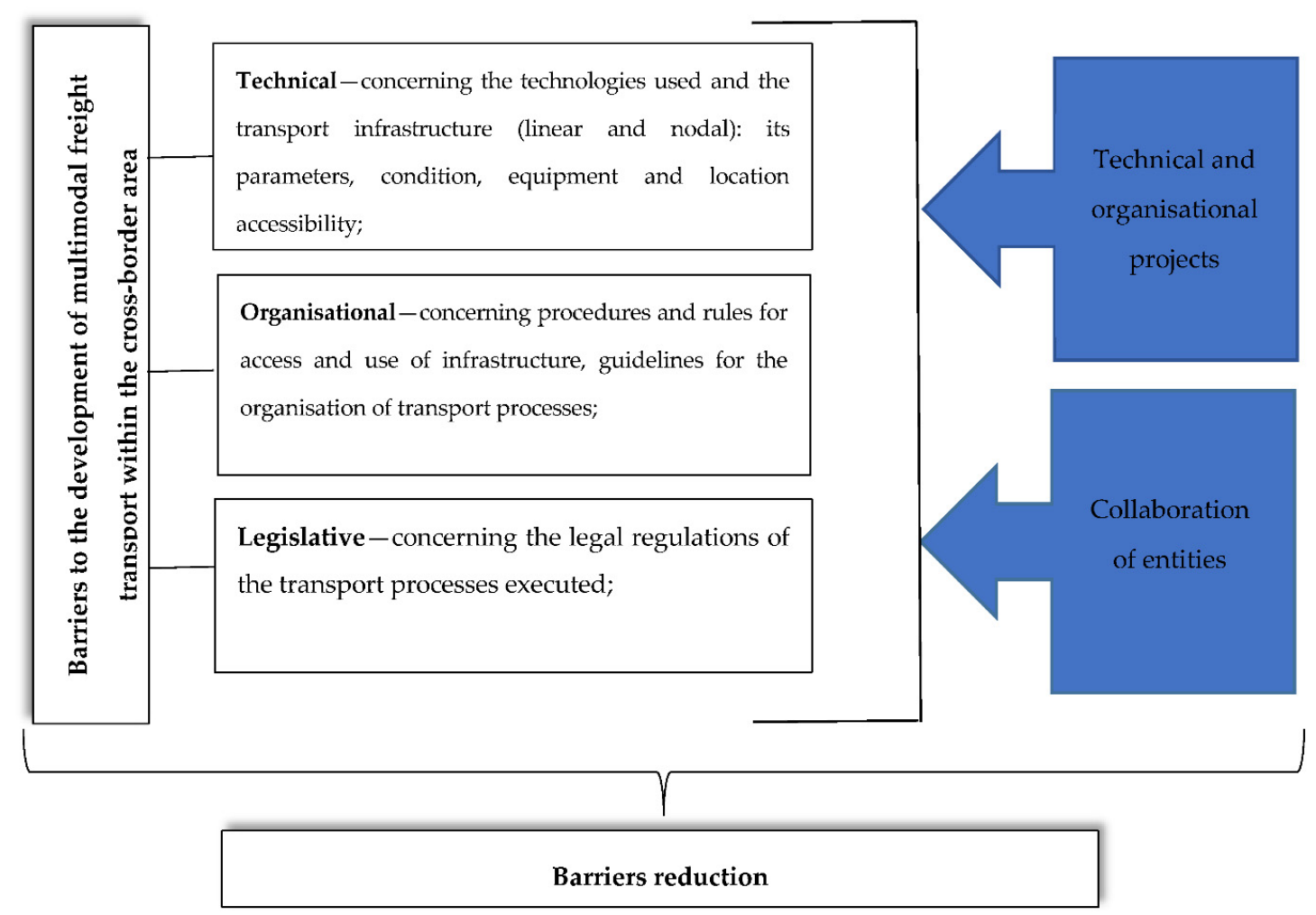

Figure 1. Barriers for multimodal freight transport development within the cross-border areas. Source: Own elaboration.

The development of transport infrastructure, both linear and nodal, is given particular attention within the cross-border multimodal transport. Its deficiencies are indicated as the main issue in building sustainable development $[30,31]$. Moreover, the development of transport corridors and the multimodal infrastructure defined in them is a strong tool for communication, cooperation and coordination between different regions [32]. What is even more important is the fact that often the infrastructure, which has mainly played a local or regional role, cannot deal with the mass flow of international freight. S. Mun and S. Nakagawa [33] indicate its importance in shaping the cross-border flows. They draw attention to the investment needs in this area, which appear with the progressing regional integration. In fact, they are essential for the success of the cross-border transport. Examples of initiatives to facilitate regional integration include the Trans-European Transport Network (TEN-T) or the Asian Land Transport Infrastructure Development (ALTID). Moreover, the impact of infrastructure investments carried out by one of the neighbouring countries on the transport costs of imports and exports of the representatives of both countries is noted, also when the other country was not involved in the investment activities. Apart from the investments in transport infrastructure, they also pay attention to the issue of the price of access to the cross-border transport infrastructure. They observe that, in this regard, there is a choice of different alternative options for the provision of transport services. In addition, each country determines its own capacity and charges for using the infrastructure on its territory. This raises the issue of eliminating barriers other than just technical ones by implementing organisational projects or proposing equivalent policies that will enable transport to move towards multimodal solutions $[33,34]$. As far as technical projects are concerned, it is also worth to mention 
the importance of nodal infrastructure and the applied loading technologies (vertical, horizontal and hybrid). They are essential due to the deficiencies in the terminal infrastructure itself, its location, accessibility and technical parameters, which affect, among others, the terminal's capacity [31,34]. Another factor worth mentioning is the cooperation and the support it provides in the form of decisions to develop these services. They are being assigned an increasing role and attention in overcoming barriers between regions within the cross-border areas [35-37]. The cooperation of entities is focused on creating new structures, systems and functionalities that do not exist at the level of individual activities. Therefore, a synergy effect emerges, which becomes an additional benefit of the undertaken cooperation [38]. Cross-border cooperation is one type of international cooperation that involves mainly local and regional authorities and, in some cases, national authorities. This cooperation takes place between two or more neighbouring administrative bodies, but the cooperation of these bodies can be complemented by setting up separate structures, communities, the main task of which is to integrate individual regions and find solutions acceptable to stakeholders. The creation and implementation of multimodal chains and their flows is a complex task requiring the cooperation of many organisations to ensure integration and coordination. This cooperation concerns not only the operators in the multimodal chain, but also the policymakers who shape the conditions in which the transport will be executed [38,39].

To summarise the above considerations, it can be stated that freight transport within the cross-border areas is a challenge due to its multidimensional nature. These dimensions refer to three main areas [40]:

- Interoperability-the necessity to adapt the infrastructure to a condition where it is possible to execute orders on both sides of the border by the same means of transport, according to the same principles;

- Interconnectivity - the necessity to increase the number, quality and efficiency of transport connections in the provision of cross-border services;

- Intermodality-the endeavour to enable a change between means and modes of transport at or near the border.

The fulfilment of these objectives requires a significant level of cooperation between all the stakeholders involved in multimodal transport and many activities focused on projects of technical, organisational and regulatory nature in the whole cross-border area. These types of solutions affecting these three main areas will allow the implementation of multimodal freight transport in accordance with the EU transport policy and the objectives of individual countries.

\subsection{Scenarios as a Method for Anticipating the Future}

During times of turbulent environment, the occurrence of events breaking the trends and the need to process and interpret information from many sources, anticipating the future becomes particularly relevant [41,42]. This significance increases when we have to deal with a pandemic situation. Nowadays, the key players (banks, financial institutions) already present pessimistic and optimistic recovery of the European economies from crises. A competition-like approach is now prevailing. Based on this approach, one can either be optimistic about 'a rapid return to the way things used to be' or pessimistic about 'nothing will ever be the same again'. Such a simple approach is usually a result of spelling reality and not a process of planning in the sense of continuous learning. It is assumed that planning itself is a process of becoming conscious of the factors and reflections relevant to the business model, and of verifying that these factors will be subject to substantial changes.

Foresight enables considering the volatility and variability of the environment in anticipation of the future. According to Keenan and Miles, foresight can be defined as the application of systematic, participatory, future-intelligence gathering and medium-to-long-term vision-building processes to make informed present-day decisions and mobilise joint actions [43]. This approach is developed by Loveridge highlighting that foresight is structurally based on the "uncomfortable marriage of 
well-structured and tested information with its counterpart subjective opinion [44]. The primary competence in foresight is the ability to think systemically, taking into account that reality is a complex process in which many coexisting factors of different nature participate-for instance: social, political, technological, cultural, ecological, or economic. The complexity of these interactions makes the future fundamentally unpredictable. The most commonly used method in regional and industry foresight projects is the scenario method, which is typically associated with such methods as the Key Technology Study, the Delphi Study and Expert Panels [41].

Scenarios, as a method to support decision-making and strategic planning, have been known for almost 60 years. However, in order to anticipate the future, scenarios were created as early as in ancient times and were related to military or philosophical concepts. The systematic use of scenarios to explain thinking about the future began after World War II, and the U.S. Department of Defense used them as a method of military planning in the 1950s [45]. In fact, Kahn, who used the word "scenario" to describe the potential future he expected in 2000, is considered a precursor of the scenario approach $[46,47]$. The popularity of using the Scenario Method for future research peaked in the 1980s, when the Shell company, after implementing one of its scenarios, recorded a spectacular success [48,49]. Over the course of nearly six decades, many concepts for defining and building scenarios have been developed. An interesting overview in this regard was presented by Duinker and Greig [50], Kanouniuk and Nazarko [41], Amer [51], Piirainen and Lindqvist [52] and Bradfield et al. [53], who quoted definitions of several authors. Interestingly, it is worth mentioning the understanding of the scenarios as:

- “... an internally consistent view of what the future might be-not a forecast, but one possible future outcome" [54];

- “... a tool for ordering one's perceptions about alternative future environments in which one's decisions might be played out" [55];

- “... part of strategic planning which relates to the tools and technologies for managing the uncertainties of the future" [56];

- “... a strategic planning tool" [48];

- " "... a set of reasonably plausible, but structurally different futures" [57];

- “... a description of a possible set of events that might reasonably take place. The main purpose of developing scenarios is to stimulate thinking about possible occurrences, assumptions relating these occurrences, possible opportunities and risks, and courses of action" [58];

- " "... a description of a future situation and the course of events which allows one to move forward from the original situation to the future" [45];

- "... alternative futures resulting from a combination of trends in driving factors and policies" [59];

- “... a complete combination of levels of impact factors for all factors. Thus, a scenario is a vector" [60];

- " "... an overall picture of the future and views of the interactions among several trends and events in the future" [61];

- " "... when developing and analysing scenarios, it should be encouraged to consider options beyond the traditional operational and conceptual comfort zone of the organisation" [62];

- “... future studies help to see the present differently and these are a devise for 'disturbing the present $^{\prime \prime \prime}[63]$

- "... scenarios help us to be prepared for the future and innovate the future" [64].

Scenarios are used in the planning, forecasting, strategic analysis and foresight research processes to take into consideration and emphasise those aspects that are critical to the forecast. It is presumed that the developed scenarios must identify possible states of the future, capture a wide range of options, stimulate thinking about the future and question the dominant thinking and status quo [65]. It is also important to encourage consideration of options beyond the traditional comfort zone and to consider non-typical situations when developing and analysing scenarios. Such encouragement can result in 
unique insights and new opportunities to be discovered. Scenario planning is, in fact, a good way to question the future [66].

Consequently, the outline of many future scenarios enables us to continuously monitor and capture factors critical to business. It can be stated that planning should be based on continuous testing of created scenarios, as in the Agile Method with project management. Over the last 50 years, scientists have developed various methods of scenario-based analysis [67-76]. The greatest number of citations were obtained from the studies by Van der Heijden and Shoemaker. The most popular method is the GBN (Global Business Network) method, which was created by Pierre Wack [67], generalised by Schwartz [55] and further developed to analyse scenarios by Van der Heijden [77]. It was used by Royal Dutch Shell [78-82].

Marcial and Costa [83] state that, apart from the GBN method, other methods that are suitable for research in the long term, i.e., the method developed by Godet [44], Porter [54], Marcial and Grumbach [84], are also worth mentioning.

\subsection{Transport Development Scenarios}

Scenario methods are often used in the study of long-term prospects for sustainable development [85], $\mathrm{CO}_{2}$ emission reduction [86], and development of smart cities [87]. In each of these areas, the "transport" factor is taken into consideration. In many cases, the authors observe the importance of including both passenger and freight transport in the research. Transport and solutions in transport networks are treated in these cases as one of many determinants of the studied issue. Scenario methods are relatively seldom used to study the development perspectives of multimodal and intermodal freight transport. The prevailing trend in the publications is that of passenger transport, while freight transport is often considered in terms of the meta-system as part of the supply chain or network [88] in the context of determining their diversification.

As far as freight transport on a macro-system scale is concerned, authors often limit themselves to examining one mode of transport. Publications in the field of road transport cover the vast majority of studies on the use of scenario methods for forecasting the development of freight transport. However, in the perspective of macro-systems and branch approaches, a growing interest of researchers in air, sea and inland waterway transport can be observed.

Publications on freight transport scenarios provide valuable information both on the methodologies used and on the choice of factors determining the development of freight transport. These factors are selected very differently and this is a result not only of the scale of the research and the specificity of the cities/countries/regions but, primarily, of the research question asked.

A scenario analysis focused on the question, "How will digitisation change freight transport?" was conducted by Pernestål et al. [19]. The authors created four scenarios and in each of them studied the impact of digitisation on the development of road freight transport, while identifying opportunities and barriers to achieving transport sustainability in each of the scenarios. In all scenarios, an increase in vehicle kilometres traveled (VKT) was foreseen, and three scenarios assumed a significant increase in recycling and urban flows. An interesting result of the study was to identify the social aspect (which is not directly linked to either digitisation or freight transport) as an influential factor that will shape the future freight transport landscape. The authors present various techniques and approaches used in scenario analysis [78]. In the article, they used the exploratory scenario according to the basic assumption that the development of the digitisation of road freight transport is inherently uncertain and that there is no single definite future for it. In fact, there are rather a few probable future developments that need to be examined in order to prepare for future events. Exploratory scenarios present different probable trajectories of development, but are not intended to present the most probable course of events (predictive scenarios) or to evaluate how the preferred scenario can be achieved (normative scenarios) [89]. In the research, the technique of Intuitive Logics (IL) was used. The Intuitive Logics is a well-established technique for exploratory scenarios $[78,89]$. 
The essence of Intuitive Logics is the analysis of trends that may impact the object under examination. Firstly, the trends are identified and mapped according to their supposed strength of impact on the object under examination. Then, the level of uncertainty as to the development of trends is estimated. Trends that are estimated to have a strong influence and low uncertainty describe an undisputed development. Among the trends that have a large impact on the system and are highly uncertain, the two most uncertain and important trends that represent strategic uncertainties are selected. Following these criteria, a $2 \times 2$ matrix is created with each quarter representing a scenario [78]. The scenario is then a representation of the future, taking into account certain developments and a certain combination of strategic uncertainties. Then, the scenarios are named, developed and analysed with an emphasis on freight transport development. An important part of the scenario building process as indicated by Pernestål et al. [19] are expert workshops. The experts were transport buyers, logistics service providers, road carriers, vehicle manufacturers, real estate companies, cities and regions, public bodies and authorities as well as transport and logistics researchers. The selection of participants was to cover a wide range of parties involved in or interacting with the freight transport sector. Between the workshops, a study group consisting of authors, one field expert and two future strategists, analysed and prepared the results generated by the workshop.

A different methodology was adopted by Bäumler [90], creating ten-year scenarios for Intelligent Transport Systems in terms of road freight transport. At the first stage, the author identified the scenario field based on the literature review. Afterwards, the author identified four areas in which the development of Intelligent Transportation Systems is focused. Then, during two workshop sessions (fifteen participants) the areas of impact, impact factors and key factors were identified. The result of these workshops was the creation of five areas of impact, as well as twenty-two impact factors, from which twelve key factors were identified. Later on, each key factor was assigned to at least one descriptive feature, which was the starting point for creating forecasts. For each key factor, packages of positive and negative forecasts were developed. These forecasts were then analysed at the third interdisciplinary conference for their consistency in terms of the ability to create correct forecast bundles. At this stage, all forecasting packages were checked using independent evaluation matrices. Finally, these results were used to create two coherent scenarios (best case and worst case scenarios) using INKA 3 Scenario Software.

In order to identify the best scenario, the package with the highest cohesion value was selected. In order to identify the worst case scenario, the package with the most deviating forecasts from the positive scenario was selected.

Publications on modes of transport other than road transport also provide important knowledge, especially in the context of developing intermodal transport. The publication on air transport development scenarios by 2030 is particularly noteworthy. Ruciński and Madej [91] observe that depending on the complexity of the issue and the level of predictability, the result of an attempt to create a forecast based on development factors may be:

- point estimation, in cases of low level of complexity and low level of uncertainty and randomness;

- deterministic model, in cases of high level of complexity and low level of uncertainty and randomness;

- confidence interval, in cases of low complexity of the issue and high level of uncertainty and randomness;

- development scenario (or stochastic model), in cases of high complexity of the issue and high level of uncertainty and randomness.

The time horizon of the study being conducted by the authors (2030) favours the use of development scenarios, as building them is one of the techniques of medium-term forecasting of the future. In such forecasting, there is a level of predictability that is possible to determine trends based on past data (predetermined factors- $\mathrm{P}$ ), with simultaneous occurrence of random variables that are impossible to identify from these trends (uncertainties-U). The procedure of building scenarios for air 
transport development by 2030 consisted of four stages: (I) identification of exogenous (external) and endogenous (internal) components, (II) evaluation of identified components in terms of trends, strength of impact and probability of occurrence, (III) ordering of factors according to probable scenarios, (IV) scenario building.

Blois and Martins [21] built a predictive model for scenarios intended to identify key investment areas in the road freight network. The primary goal adopted in the scenario analysis was to reduce pollution. The authors use a combination of quantitative methods, and statistical analysis of trends in individual factors identified at the expert analysis stage. The first stage of the research in the methodology adopted by Blois and Martins was to identify the problem to be analysed in a scenario analysis and to identify the factors describing the issue. At this stage, the authors used the literature research and expert opinions (Delphi Panel). The second stage was historical studies on the identified factors. Expert opinions (Delphi) were also used by the authors at the next stage, which focused on determining the impact of particular trends on the future development of road freight transport. The authors used Cross-Impact Matrix and Median Impact Matrix to build the scenario. At the last stage, the authors used system dynamics to support investment decisions. The authors refer to earlier publications that combine prospective scenarios with the dynamics of the management systems, including Blois and Suoza [92], indicating that such an approach enables the integration of quantitative and qualitative description of occurrences. Such an approach is invaluable because it allows for an interdisciplinary discussion that brings together different areas of knowledge, which is essential whenever greater cohesion in scenario building is to be achieved.

A similar methodology in building prospective scenarios for a slightly different research problem- $-\mathrm{CO}_{2}$ emissions reduction in relation to the consequences of different policies for key network entities-was adopted by Brand et al. [22]. The authors used the following steps to reach the scenarios: presentation and analysis of destructive changes in the transport energy system, development of destructive scenarios and more gradual changes in the transport system for $\mathrm{CO}_{2}$ emissions reduction, and identification of the most beneficial solutions for the stakeholders. During the development of the scenarios, the authors focused their attention on distortions in the coordination of flows in the transport system and the continuity of changes introduced to reduce $\mathrm{CO}_{2}$ emission by comparing maps of strategic policies and their effects.

No matter what model is adopted, the first stage of scenario analysis is to study economic phenomena, identify the regularities governing economic processes and formulate general conclusions.

An interesting perspective on the development of intermodal transport is the use of scenario analysis by Reggiani et al. [93]. The authors first presented a short-, medium- and long-term perspective resulting from the provisions of strategic documents at the level of countries and the European Union. They identified steps to achieve the set goals: standardisation of transport policy goals, sustainable development of transport systems, integration of transport infrastructure, integration of transport network, and added value. Next, the authors indicated barriers in each of these steps. When analysing the current trends in the development of intermodal transport in the transalpine sector, the authors suggested the following scenarios:

Scenario 1: Without new infrastructure (DFTCE-Federal Department of Transports Communications and Energies scenario)

Scenario 2: With new rail line

Scenario 3: New infrastructure projects (Prognos-PROGNOS AG, REGIONAL CONSULTING scenario)

Scenario 4: New infrastructure projects (C.A.R.-Committee of Alpine Railways scenario)

A: Favourable scenario for rail mode

B: Less favourable scenario for rail mode 
When analysing individual scenarios according to the probability of factors determining them, the authors have narrowed further analyses to two scenarios. The research problem of this publication is similar to the problem raised in this paper. It concerns intermodal transport and freight flows within the cross-border areas.

\section{Methodology of the Study}

Literature research allowed for identifying the problems related to the development of multimodal transport within the cross-border areas and formulating the following research questions:

1. What factors have the greatest impact on the development of multimodal transport within the cross-border area of Poland-Czech Republic_-Slovakia in the 2030 perspective?

2. What are the visions for the development of multimodal transport in the TRITIA cross-border area in the 2030 perspective and how do they depend on collaboration and joint activities?

3. What trends in key factors describe the presented visions for the development of multimodal transport in the TRITIA area, and what is the probability of the particular scenarios occurring in the 2030 perspective?

4. What group of projects is necessary to be implemented when a specific scenario occurs?

In the paper, a method of creating scenarios of the multimodal transport development in the cross-border area was used in the perspective of 2030, combining expert research and foresight approach. The creation of scenarios constitutes a complement of the research on the strategy of the multimodal freight transport development, conducted as a part of INTERREG TRANS TRITIA project, while the method of creating scenarios complements the methodology of designing the development strategies. The approach to creating scenarios proposed in the article is compliant with concepts presented in the literature. Successful scenario building combined with the technical competence to use a specific methodology-requires futurology-an approach based on the belief that the future is a resource that can be shaped in an active and positive way [94]. It was assumed that the process of scenario building is a logical and formal construction of alternative visions of the desired future based on the involvement of heterogeneous groups of experts that ensures thorough knowledge and understanding of the factors shaping the studied problem and enables making rational decisions about the future [95]. The research was based on the GBN method, and approaches proposed by Godet [96] and Blois and Suoza [92]. The research presented by the authors assumed:

- developing a vision of the future in four scenarios,

- applying qualitative variables,

- analyses of trends to evaluate the importance and probability of occurrence,

- detailed description of the tools used at all stages,

- $\quad$ utilisation of qualitative methods (expert analyses, trend analyses).

The study concerned the cross-border region of Poland, Slovakia and Czech Republic associated in the European Grouping of Territorial Cooperation TRITIA (EGTC TRITIA). It was established on 25 February 2013 by the decision of the Minister of Foreign Affairs of the Republic of Poland, no. 1/2013 named EGTC TRITIA and entered into the Register of European Groupings of Territorial Cooperation administered by the Ministry of Foreign Affairs of Poland. The decision to establish the EGTC TRITIA was already made in 2009 by the leaders of local governments from the Moravian-Silesian Region (Cz), the Opole Voivodeship (PL), the Silesian Voivodeship (PL) and the Žilina Self-Governing Region (SK), and based on this decision, steps were taken to establish the Grouping. The decision of the regional authorities followed the positive experience of the cross-border and interregional cooperation and its impact on the quality of life of the inhabitants of the cross-border areas. 
The EGTC TRITIA covers an area of 24,566.09 square kilometres and has almost 6.5 million inhabitants. There are two cities with more than 300,000 inhabitants in the area-Katowice (PL) and Ostrava (Cz). Two large urban agglomeration areas together with Žilina (SK) are tied by intensive socio-economic relations. The fact that the EGTC TRITIA is located on the Baltic-Adriatic Transport Corridor axis creates new opportunities for investment and interregional relations. There are seven universities, well-developed tertiary education, and an environment fostering innovation and R\&D activities. Due to the relations between the different entities within the territory of the EGTC TRITIA, and to the common challenges, there is a great potential for increasing the intensity, systematisation and multilateral partnership of the regions concerned. The main objective of the EGTC TRITIA in the field of transport is to maximise the use of the geographical location of the partner regions for their economic development, supported by the appropriate development of the cross-border transport and transport infrastructure. The endogenous potential of the regions involved and the need for accessibility and safety are utilised with respect for the environment and sustainable development [97]. The results of past research conducted within the project allowed to adopt the assumptions of creating scenarios and indicated two key factors of the freight transport development in the TRITIA cross-border area: cooperation between the stakeholders of all three countries and systemic (compatible, coordinated) implementation of organisational and infrastructure projects in all cross-border regions.

A detailed research process is presented in Figure 2.

According to the research process presented in Figure 2, the different steps in developing multimodal transport scenarios in the TRITIA cross-border area are as follows:

- Identification of factors affecting the development of multimodal transport within the cross-border area

The process of collecting the data required to identify the factors had two phases. The first phase included literature research, according to which, potential factors influencing the development of multimodal transport were identified. The analyses of factors of freight transport development, their trends, impact strengths and directions of influence have been conducted by the authors for several years now $[17,98,99]$. It is due to the fact that these factors can vary depending on the approach concerning one branch of transport or multimodality, and on the area which covers national, international or cross-border freight transport. Therefore, it is possible to identify a group of factors common to all analyses concerning the development of freight transport, and to distinguish determinants specific to the area concerned. In order to indicate the factors, the authors used the analysis of scientific publications (both national and international), the analysis of a number of reports and statistics $[98,99]$ showing the trends observed on the transport market and the impact they have on the structure of freight transport.

In a second phase (using a questionnaire), the identified factors were discussed in a workshop with a team of experts and stakeholders (representatives of the scientific community, stakeholders involved in multimodal transport, including national and regional authorities, linear and nodal infrastructure managers, and entities responsible for the execution of freight transport), who had the primary task of eliminating unnecessary factors and adding new and relevant determinants to their list, and then defining the final list of factors having the greatest impact on the development of multimodal transport within the cross-border areas. The workshops covered both the completion of the developed questionnaire by the experts and the panel discussion moderated by the authors of the publication. Finally, there were 45 factors selected. 


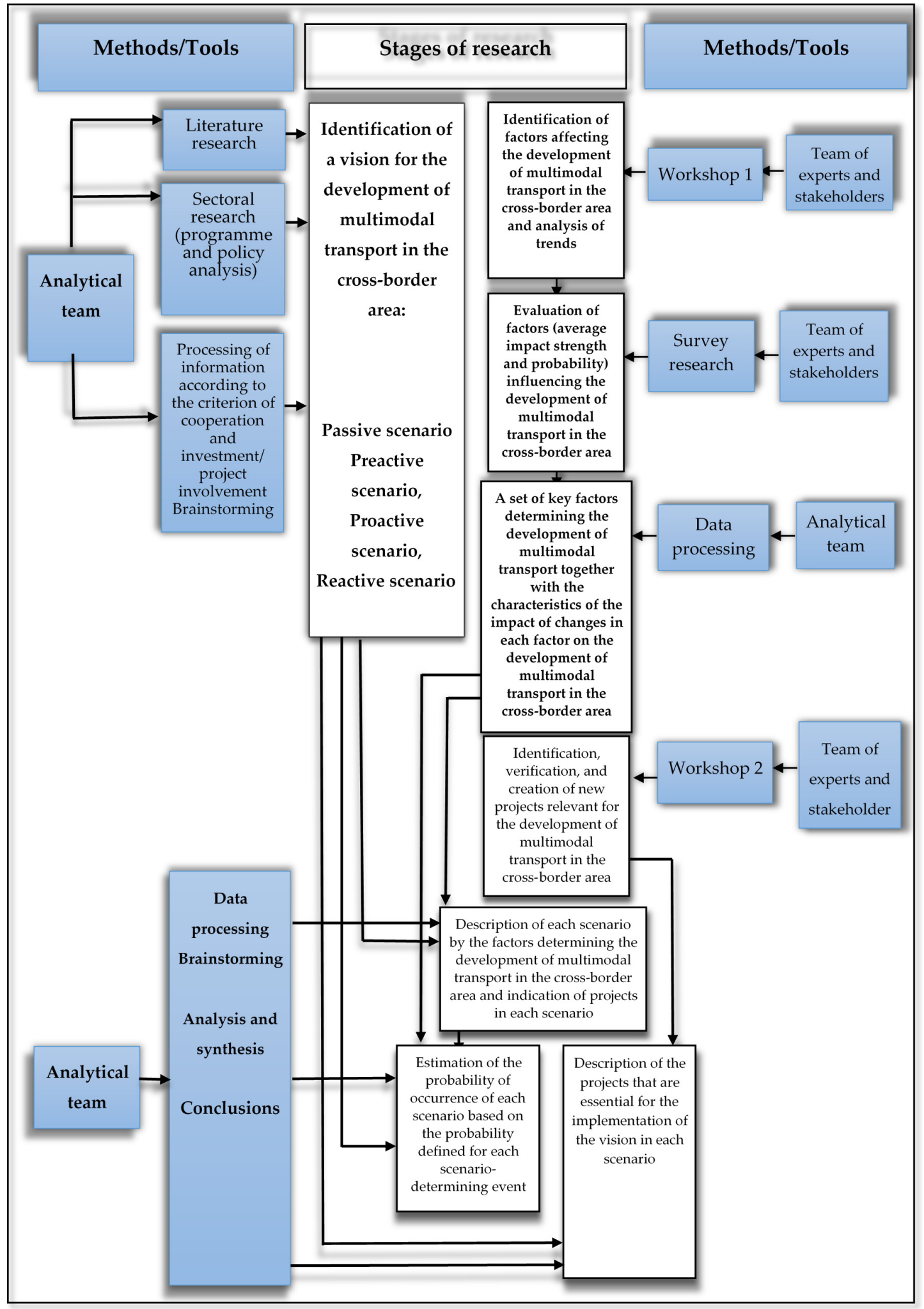

Figure 2. Research process. Source: Own elaboration.

- Evaluation of identified factors affecting the development of multimodal transport within the cross-border area

At the next step, a study to evaluate the identified factors was conducted with the help of a team of experts and stakeholders in multimodal transport. For this purpose, a questionnaire was developed to determine the trend of change for each factor and the impact strength and direction on 
the development of multimodal transport within the cross-border area. The questionnaire was sent to the same experts who had filled it out individually, which increased the credibility of the research results. In this way, a number of pieces of information related to the anticipated development of individual factors was obtained. Evaluation of the impact strength of the identified determinants was assumed to be the basis for the identification of key factors. To evaluate them, a standard scale was adopted ranging from -3 to +3 . The study assumed that the absolute value of 3 indicates the strongest impact, and the absolute value of 1 indicates the weakest impact, whereas 0 indicates no impact. Moreover, positive or negative values indicate the direction of the impact-supporting (positive) or hindering (negative) the development of multimodal transport within the examined cross-border area. For the purpose of determining the set of key factors, the impact strengths assigned by all experts separately for particular trends were averaged. Additionally, in order to rule out the randomness of the experts' evaluation, the level of their compliance in the assessment of individual factors was examined, using the Krippendorff's alpha coefficient. This reliability coefficient is considered to be the most universal measure which has no restrictions on the measurement scale used (nominal, interval, ordinal). Additionally, the applicability of the coefficient was due to the adjustment of the coefficient to the number of experts, the number of factors evaluated or the adopted evaluation scale. The coefficient takes values from -1 (total non-compliance) to +1 (total compliance), 0 means compliance at the case level. In view of the adopted assumptions, the coefficient of experts' compliance was determined for individual analysed factors.

- Identification of a set of key factors determining the development of multimodal transport combined with the characteristics of the impact of changes in each factor on the development of multimodal transport within the cross-border area

The next step was to identify a set of key factors among the factors selected for analysis, for which the level of expert compliance was at least satisfactory. It was presumed that in accordance with the Pareto principle (20/80 rule), the set of key factors will include $20 \%$ of the highest scores among all the factors identified at the first stage of the study. The average evaluation of the strength of impact, as determined by the experts conducting the analysis, was adopted as the criterion for identification.

- Identification, verification and generation of new projects essential for the development of multimodal transport within the cross-border area

The next step included two research phases. Firstly (using a questionnaire), projects essential for the development of multimodal transport in the TRITIA cross-border area were identified. Then, another workshop with the participation of experts and stakeholders in multimodal transport was conducted, during which the identified projects were verified, and later, on the basis of the discussion moderated by the authors of the paper, new projects were generated, which were necessary to implement the vision of multimodal transport development in the area under analysis.

The basis for identification of the projects was the strategic assumptions contained in the White Paper and the strategic objectives for the development of multimodal transport in the TRITIA area. The presentation of the projects included several stages:

- Identification of infrastructure projects which have an impact on the development of multimodal transport on the border between Poland and Slovakia, Poland and Czech Republic, Slovakia and Czech Republic. The selected projects were based on an extensive analysis of strategic programmes written at international, national or regional level, with a particular focus on the development of multimodal transport for the TRITIA area. It was presumed that projects may be in the process of implementation or are planned for implementation.

- Identification of new projects developing multimodal transport in the TRITIA area, which are a proposal to overcome bottlenecks and respond to the needs of key stakeholders (at national and regional level). 
- Identification of a vision for the development of multimodal transport within the cross-border area

Concurrently with the previous steps, based on extensive literature research and analysis of national, regional and sectoral programmes and policies for the TRITIA cross-border area, four visions for the development of multimodal transport were identified. The key criteria for the identification of the visions were the degree of cooperation and the degree of technical and organisational involvement of stakeholders in the development of multimodal transport within the cross-border area. The degree of cooperation, and more specifically, the degree of collaboration, means, in particular, the sharing of information on multimodal transport and information on disruptions in material flows between countries, freedom of information exchange, and joint activities to develop cross-border transport. The support of multimodal transport solutions is widely treated as the development of infrastructure solutions (including both linear, nodal and information infrastructure), as well as support of organisational solutions focused on synchronisation and coordination of flows within the cross-border area. The developed visions are the effect of the work of the analytical team, however, they are based on data collected at previous steps of the research process. In this context, the approach of M. Godet [100] was used, which indicates four possible attitudes towards the future:

1. Passive, which consists of passive submission to the upcoming reality.

2. Reactive, which consists of violent activities that mitigate the effects of unexpected events.

3. Preactive, which consists of preparing for the expected course of events.

4. Proactive, which consists of initiating activities to generate the desired changes.

- $\quad$ Conceptual work of the analytical team

At the last step, the analytical team described each of the scenarios identified at the stage of expert research by the projects. Applying the projects developed during the second workshop to the identified scenarios allowed the analytical team to describe the scenarios according to the support requirements for their implementation. After that, the team estimated the probability of occurrence of each of the scenarios. The probability of scenario occurrence was estimated based on the average value of the probability of trends. The work of the analytical team consisted primarily in processing the information available and collected at the previous steps, the analysis and synthesis of this information and, as a result, drawing conclusions_-often based on the brainstorming method.

\section{Results}

\subsection{Identification of Key Factors for the Development of Multimodal Freight Transport within the Cross-Border Area}

Table 1 presents the results of the research concerning the identification of key factors for the development of multimodal freight transport in the TRITIA cross-border area. The final set of multimodal transport factors is divided into four main spheres: economic, political and legal, socio-cultural and environmental, and technological. The set was indicated as a result of the conducted literature research and moderated workshop with the participation of experts and stakeholders of the multimodal transport (the description of research was presented in Section 3 of the paper). 
Table 1. Identified factors for the development of multimodal transport in the TRITIA cross-border area.

\begin{tabular}{|c|c|}
\hline Group & Factors \\
\hline 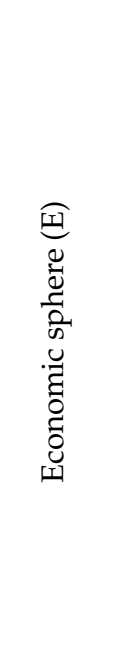 & $\begin{array}{l}\text { 1. The level of GDP per capita } \\
\text { 2. The level of financial support from the state in the development of } \\
\text { 3. State expenditure on the development of linear and nodal infrastructure of } \\
\text { various transport branches } \\
\text { 4. The level of demand for inter-branch transport } \\
\text { 5. The price level of services in the road transport } \\
\text { 6. The price level of services in the rail and inland waterway } \\
\text { 7. Level of international transit and commercial exchange } \\
\text { 8. Accessibility to sources of financing transport investments } \\
\text { 9. The level of uniformity of financing the individual branches of transport } \\
\text { 10. Internalisation of the external transport costs } \\
\text { 11. Exchange rates } \\
\text { 12. Discount level in multimodal transport } \\
\text { 13. Raw material costs (fuel, energy, etc.) } \\
\text { 14. Costs of access to off-road infrastructure }\end{array}$ \\
\hline 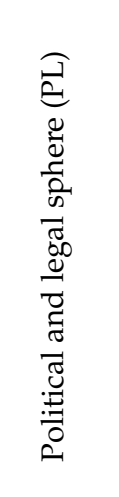 & $\begin{array}{l}\text { 1. The level of convergence of the transport policy guidelines of neighbouring } \\
\text { 2. Number of agreements between countries and regions regarding transport } \\
\text { 3. The level of harmonisation of transport legislation in individual countries } \\
\text { 4. The number and degree of implementation of the state programmes formulated } \\
\text { for the development of multimodal transport } \\
\text { 6. Level of lobbying for sustainable transport } \\
\text { 7. Level lobbying inhibiting growth of sustainable transport } \\
\text { 8. The level of spatial coherence } \\
\text { 9. The level of coordination of the local government structures and government } \\
\text { administration in regions }\end{array}$ \\
\hline 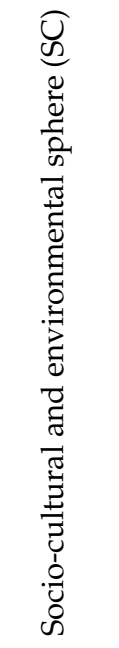 & $\begin{array}{l}\text { 1. Population density level } \\
\text { 2. Urbanisation level } \\
\text { 3. Income level of population } \\
\text { 4. The level of social external costs of transport } \\
\text { 5. The level of awareness of enterprises and society in relation to ecological aspects } \\
\text { 6. Climate variability and surface features } \\
\text { 7. Occurrence of natural hazards (landslides, mining damage, crashes, floods) } \\
\text { 8. The number of pro-ecological organisations and actions aimed at the }\end{array}$ \\
\hline
\end{tabular}


Table 1. Cont.

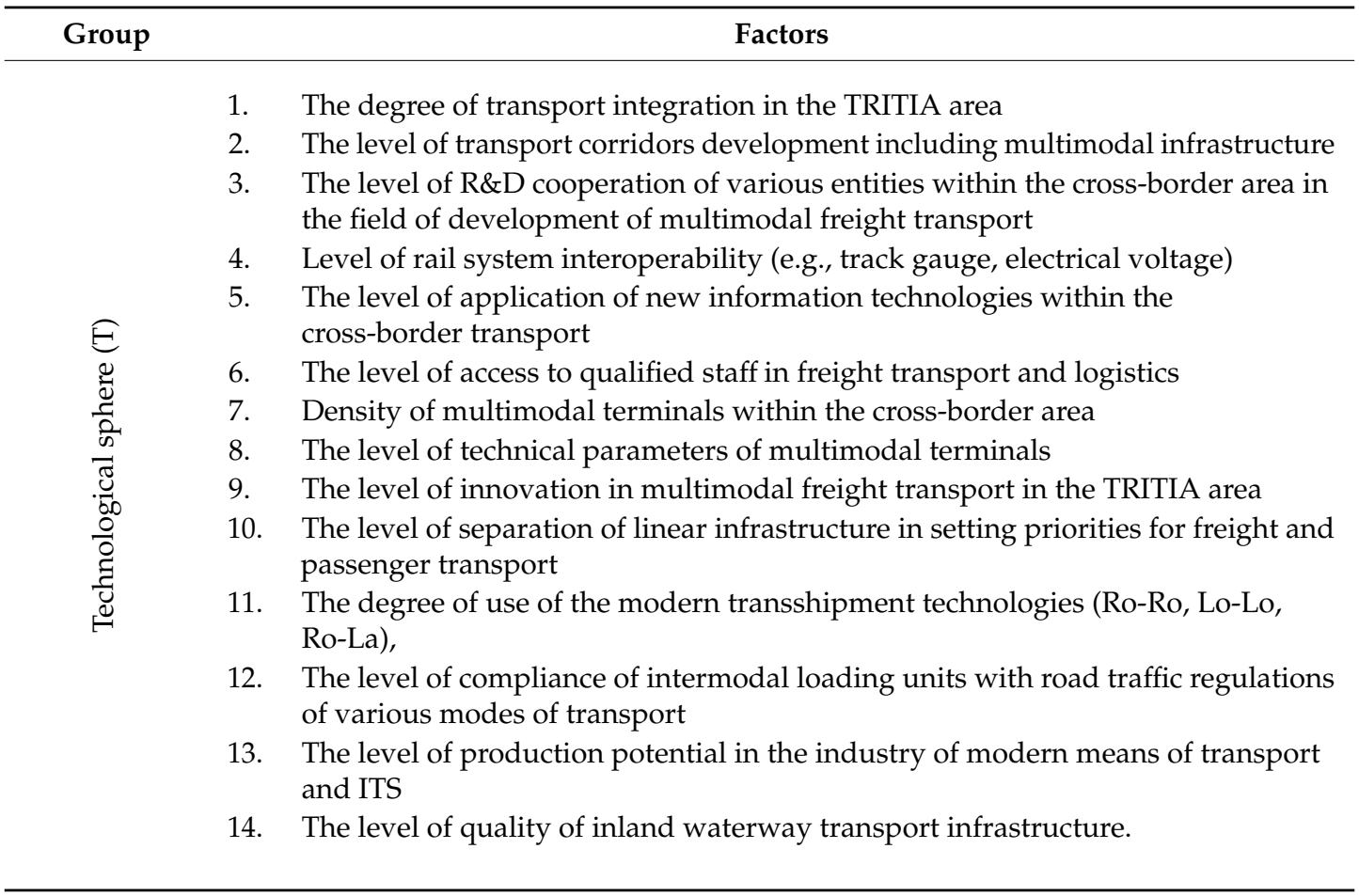

Source: Own elaboration.

4.2. Evaluation of Factors (Strength of Impact and Probability) Affecting the Development of Multimodal Transport within the Cross-Border Area

Table 2 presents the results of a study on the evaluation of groups of factors affecting the development of multimodal transport in the TRITIA cross-border area. The source of information included in the table was the research conducted with the use of a survey questionnaire, in which 15 experts and stakeholders of the multimodal transport have participated. The research was conducted in accordance with the rules included in the research process presented in Figure 2, discussed in Section 3 of the article. 
Table 2. The results of a study.

\begin{tabular}{|c|c|c|c|c|c|c|c|c|c|c|c|c|c|c|c|}
\hline \multirow[b]{3}{*}{ Factors Group } & \multirow[b]{3}{*}{ Trend } & \multicolumn{14}{|c|}{ Factor Number } \\
\hline & & \multicolumn{2}{|r|}{1} & \multicolumn{2}{|r|}{2} & \multicolumn{2}{|r|}{3} & \multicolumn{2}{|r|}{4} & \multicolumn{2}{|r|}{5} & \multicolumn{2}{|r|}{6} & \multicolumn{2}{|r|}{7} \\
\hline & & $\begin{array}{l}\text { Average } \\
\text { Impact } \\
\text { Strength } \\
\text { Rating }\end{array}$ & $\begin{array}{l}\text { Average } \\
\text { Probability } \\
\text { of a Trend }\end{array}$ & $\begin{array}{l}\text { Average } \\
\text { Impact } \\
\text { Strength } \\
\text { Rating }\end{array}$ & $\begin{array}{l}\text { Average } \\
\text { Probability } \\
\text { of a Trend }\end{array}$ & $\begin{array}{l}\text { Average } \\
\text { Impact } \\
\text { Strength } \\
\text { Rating }\end{array}$ & $\begin{array}{c}\text { Average } \\
\text { Probability } \\
\text { of a Trend }\end{array}$ & $\begin{array}{l}\text { Average } \\
\text { Impact } \\
\text { Strength } \\
\text { Rating }\end{array}$ & $\begin{array}{l}\text { Average } \\
\text { Probability } \\
\text { of a Trend }\end{array}$ & $\begin{array}{l}\text { Average } \\
\text { Impact } \\
\text { Strength } \\
\text { Rating }\end{array}$ & $\begin{array}{c}\text { Average } \\
\text { Probability } \\
\text { of a Trend }\end{array}$ & $\begin{array}{l}\text { Average } \\
\text { Impact } \\
\text { Strength } \\
\text { Rating }\end{array}$ & $\begin{array}{c}\text { Average } \\
\text { Probability } \\
\text { of a Trend }\end{array}$ & $\begin{array}{l}\text { Average } \\
\text { Impact } \\
\text { Strength } \\
\text { Rating }\end{array}$ & $\begin{array}{c}\text { Average } \\
\text { Probability } \\
\text { of a Trend }\end{array}$ \\
\hline \multirow{3}{*}{$\begin{array}{l}\text { Economic } \\
\text { Sphere }\end{array}$} & Growth & 1.78 & 0.47 & 2.00 & 0.37 & 2.39 & 0.51 & 1.44 & 0.45 & 2.11 & 0.62 & -1.44 & 0.50 & 2.28 & 0.69 \\
\hline & Stabilisation & 0.56 & 0.31 & 0.78 & 0.40 & 1.06 & 0.31 & 0.00 & 0.39 & 0.44 & 0.32 & 0.44 & 0.39 & 0.56 & 0.22 \\
\hline & Regress & -1.33 & 0.23 & -1.22 & 0.53 & -1.56 & 0.17 & -1.22 & 0.16 & -1.61 & 0.07 & 1.00 & 0.10 & -1.39 & 0.09 \\
\hline \multirow{3}{*}{$\begin{array}{l}\text { Political and } \\
\text { Legal Sphere }\end{array}$} & Growth & 1.83 & 0.48 & 1.44 & 0.51 & 2.00 & 0.54 & 1.89 & 0.39 & 1.89 & 0.44 & 0.50 & 0.36 & 2.06 & 0.39 \\
\hline & Stabilisation & 0.22 & 0.41 & 0.78 & 0.38 & 0.44 & 0.36 & 0.06 & 0.40 & 0.44 & 0.38 & 0.06 & 0.39 & 0.94 & 0.47 \\
\hline & Regress & -1.94 & 0.11 & -1.33 & 0.10 & -1.44 & 0.09 & -2.00 & 0.19 & -1.78 & 0.17 & -1.61 & 0.24 & -1.61 & 0.14 \\
\hline \multirow{3}{*}{$\begin{array}{l}\text { Technological } \\
\text { Sphere }\end{array}$} & Growth & 2.11 & 0.54 & 2.78 & 0.73 & 1.33 & 0.51 & 2.06 & 0.53 & 1.61 & 0.64 & 1.56 & 0.41 & 2.11 & 0.45 \\
\hline & Stabilisation & 0.44 & 0.38 & 0.39 & 0.23 & 0.39 & 0.38 & 0.89 & 0.43 & 0.50 & 0.30 & 0.11 & 0.39 & 0.67 & 0.52 \\
\hline & Regress & -1.56 & 0.08 & -1.67 & 0.04 & -0.72 & 0.11 & -0.89 & 0.04 & -1.00 & 0.06 & -1.44 & 0.19 & -1.56 & 0.03 \\
\hline \multirow{3}{*}{$\begin{array}{l}\text { Socio-Cultural } \\
\text { and } \\
\text { Environmental } \\
\text { Sphere }\end{array}$} & Growth & 1.61 & 0.16 & 1.44 & 0.30 & 1.94 & 0.63 & 1.28 & 0.38 & 1.33 & 0.59 & -1.06 & 0.48 & -1.61 & 0.53 \\
\hline & Stabilisation & 0.72 & 0.59 & 0.67 & 0.54 & 0.50 & 0.28 & 0.44 & 0.36 & 0.39 & 0.33 & 0.11 & 0.38 & 0.33 & 0.37 \\
\hline & Regress & -0.78 & 0.24 & -0.72 & 0.16 & -1.06 & 0.08 & -0.83 & 0.25 & -0.78 & 0.09 & 0.72 & 0.14 & 0.83 & 0.09 \\
\hline
\end{tabular}


Table 2. Cont.

\begin{tabular}{|c|c|c|c|c|c|c|c|c|c|c|c|c|c|c|c|}
\hline \multirow[b]{2}{*}{ Factors Group } & \multirow[b]{2}{*}{ Trend } & \multicolumn{2}{|r|}{8} & \multicolumn{2}{|r|}{9} & \multicolumn{2}{|r|}{10} & \multicolumn{2}{|c|}{11} & \multicolumn{2}{|c|}{12} & \multicolumn{2}{|c|}{13} & \multicolumn{2}{|c|}{14} \\
\hline & & $\begin{array}{l}\text { Average } \\
\text { Impact } \\
\text { Strength } \\
\text { Rating } \\
\end{array}$ & $\begin{array}{c}\text { Average } \\
\text { Probability } \\
\text { of a Trend }\end{array}$ & $\begin{array}{l}\text { Average } \\
\text { Impact } \\
\text { Strength } \\
\text { Rating }\end{array}$ & $\begin{array}{c}\text { Average } \\
\text { Probability } \\
\text { of a Trend }\end{array}$ & $\begin{array}{l}\text { Average } \\
\text { Impact } \\
\text { Strength } \\
\text { Rating } \\
\end{array}$ & $\begin{array}{c}\text { Average } \\
\text { Probability } \\
\text { of a Trend }\end{array}$ & $\begin{array}{l}\text { Average } \\
\text { Impact } \\
\text { Strength } \\
\text { Rating }\end{array}$ & $\begin{array}{c}\text { Average } \\
\text { Probability } \\
\text { of a Trend }\end{array}$ & $\begin{array}{l}\text { Average } \\
\text { Impact } \\
\text { Strength } \\
\text { Rating } \\
\end{array}$ & $\begin{array}{c}\text { Average } \\
\text { Probability } \\
\text { of a Trend }\end{array}$ & $\begin{array}{l}\text { Average } \\
\text { Impact } \\
\text { Strength } \\
\text { Rating }\end{array}$ & $\begin{array}{c}\text { Average } \\
\text { Probability } \\
\text { of a Trend }\end{array}$ & $\begin{array}{l}\text { Average } \\
\text { Impact } \\
\text { Strength } \\
\text { Rating }\end{array}$ & $\begin{array}{c}\text { Average } \\
\text { Probability } \\
\text { of a Trend }\end{array}$ \\
\hline \multirow{3}{*}{$\begin{array}{l}\text { Economic } \\
\text { Sphere }\end{array}$} & Growth & 1.89 & 0.43 & 0.56 & 0.21 & 2.50 & 0.52 & 0.39 & 0.26 & 1.83 & 0.28 & 1.61 & 0.70 & 0.28 & 0.45 \\
\hline & Stabilisation & 1.17 & 0.34 & 0.33 & 0.47 & -0.11 & 0.42 & 0.44 & 0.54 & 0.78 & 0.53 & 0.50 & 0.22 & -0.17 & 0.38 \\
\hline & Regress & -1.17 & 0.22 & -1.06 & 0.31 & -2.00 & 0.06 & -0.94 & 0.20 & -0.94 & 0.19 & -1.28 & 0.08 & -0.89 & 0.17 \\
\hline \multirow{3}{*}{$\begin{array}{l}\text { Political and } \\
\text { Legal Sphere }\end{array}$} & Growth & 1.22 & 0.42 & 1.72 & 0.45 & & & & & & & & & & \\
\hline & Stabilisation & 0.67 & 0.45 & 0.39 & 0.39 & & & & & & & & & & \\
\hline & Regress & -0.72 & 0.12 & -1.22 & 0.15 & & & & & & & & & & \\
\hline \multirow{3}{*}{$\begin{array}{l}\text { Technological } \\
\text { Sphere }\end{array}$} & Growth & 1.78 & 0.49 & 1.78 & 0.65 & 2.33 & 0.56 & 2.28 & 0.46 & 2.11 & 0.46 & 1.61 & 0.74 & 2.06 & 0.36 \\
\hline & Stabilisation & 0.39 & 0.42 & 0.44 & 0.28 & 0.72 & 0.38 & 0.94 & 0.44 & 0.78 & 0.47 & 0.61 & 0.19 & -0.11 & 0.48 \\
\hline & Regress & -1.56 & 0.09 & -1.17 & 0.07 & -1.72 & 0.06 & -1.56 & 0.10 & -1.28 & 0.06 & -1.22 & 0.07 & -1.94 & 0.16 \\
\hline \multirow{3}{*}{$\begin{array}{c}\text { Socio-Cultural } \\
\text { and } \\
\text { Environmental } \\
\text { Sphere } \\
\end{array}$} & Growth & 0.94 & 0.31 & & & & & & & & & & & & \\
\hline & Stabilisation & 0.56 & 0.47 & & & & & & & & & & & & \\
\hline & Regress & -0.89 & 0.22 & & & & & & & & & & & & \\
\hline
\end{tabular}


Table 3 presents the results of the expert compliance calculations using the Krippendorff's alpha coefficient. It was calculated using the Statistica software with the Zestaw Plus extension used for statistical data analysis. In the research, the level of consistency of 15 experts evaluating 45 identified factors of the multimodal transport development was taken into account. The source of data for determining the indicator were the results of conducted survey research aimed at evaluating the identified factors. The averaged results of the expert evaluation of specific factors were included in Table 2. They constitute a research result compliant with the stages presented in Figure 2, discussed in Section 3 of the paper.

Table 3. The experts' level of compliance.

\begin{tabular}{|c|c|c|c|c|c|c|c|c|c|c|c|c|c|c|}
\hline \multirow{2}{*}{ Factor Group } & \multicolumn{14}{|c|}{ Factor Number } \\
\hline & 1 & 2 & 3 & 4 & 5 & 6 & 7 & 8 & 9 & 10 & 11 & 12 & 13 & 14 \\
\hline Economic & 0.78 & 0.58 & 0.82 & 0.57 & 0.70 & 0.52 & 0.80 & 0.70 & 0.31 & 0.82 & 0.20 & 0.62 & 0.49 & 0.15 \\
\hline Political-legal & 0.69 & 0.79 & 0.82 & 0.69 & 0.63 & 0.38 & 0.79 & 0.62 & 0.67 & - & - & - & - & - \\
\hline Technological & 0.72 & 0.87 & 0.64 & 0.68 & 0.65 & 0.61 & 0.69 & 0.64 & 0.73 & 0.69 & 0.77 & 0.70 & 0.69 & 0.65 \\
\hline $\begin{array}{l}\text { Socio-cultural } \\
\text { and } \\
\text { environmental }\end{array}$ & 0.54 & 0.5 & 0.69 & 0.54 & 0.53 & 0.43 & 0.56 & 0.40 & - & - & - & - & - & - \\
\hline
\end{tabular}

Source: Own elaboration based on Statistica software.

In order to interpret the experts' level of compliance, determined by the Krippendorff's alpha coefficient, the experts' compliance evaluations in Table 4 have been adopted.

Table 4. Krippendorff's alpha coefficient values of the experts' level of compliance.

\begin{tabular}{cccc}
\hline Coefficient & Compliance Level & Coefficient & Compliance Level \\
\hline$>0.80$ & very good & $0.4-0.6$ & acceptable \\
$0.6-0.8$ & good & $<0.4$ & insufficient \\
\hline
\end{tabular}

Source: https://media.statsoft.pl/pdf/czytelnia/wykorzystywanie_procedury_sedziow_kompetentnych.pdf.

The analysis of the obtained level of compliance of experts using the Krippendorff's alpha coefficient allows concluding that for 40 factors, the compliance level is at an acceptable level $(>0.40)$. In the case of five factors (three economic, one political-legal and one of the group of socio-cultural and environmental factors), the experts' compliance is at an insufficient level, which, in consequence, results in their rejection at further stages of the research (marked in grey in the table). This is the result of uncertainty as to the reliable and certain evaluation of these factors. For the remaining 40 factors, for 10 of them, the level of experts' compliance is satisfactory, for four of them, it is very good, while the most (as many as 26 factors) is good. Comparing the four main groups of factors, it can be observed that the lowest level of compliance, taking into account acceptable factors, refers to the socio-cultural and environmental sphere. There are noticeable discrepancies between the experts in evaluating the impact of these factors on the level of development of multimodal transport within the cross-border area. The highest level of consensus, however, is visible in two groups of factors: technological and political-legal.

\subsection{Identification of a Set of Key Factors Determining the Development of Multimodal Transport}

According to the methodology adopted and based on the results of the previous stage of research, the number of key factors should amount to nine (according to the Pareto principle, the set of key factors will include $20 \%$ of the highest rated factors out of all 45 identified factors). However, due to the fact that as many as four factors have the same rating, representing the limits of the identified factors (2.11), there were 10 determinants considered to be key to the development of multimodal cross-border transport. These determinants together with their average strength of influence are presented in Figure 3. 


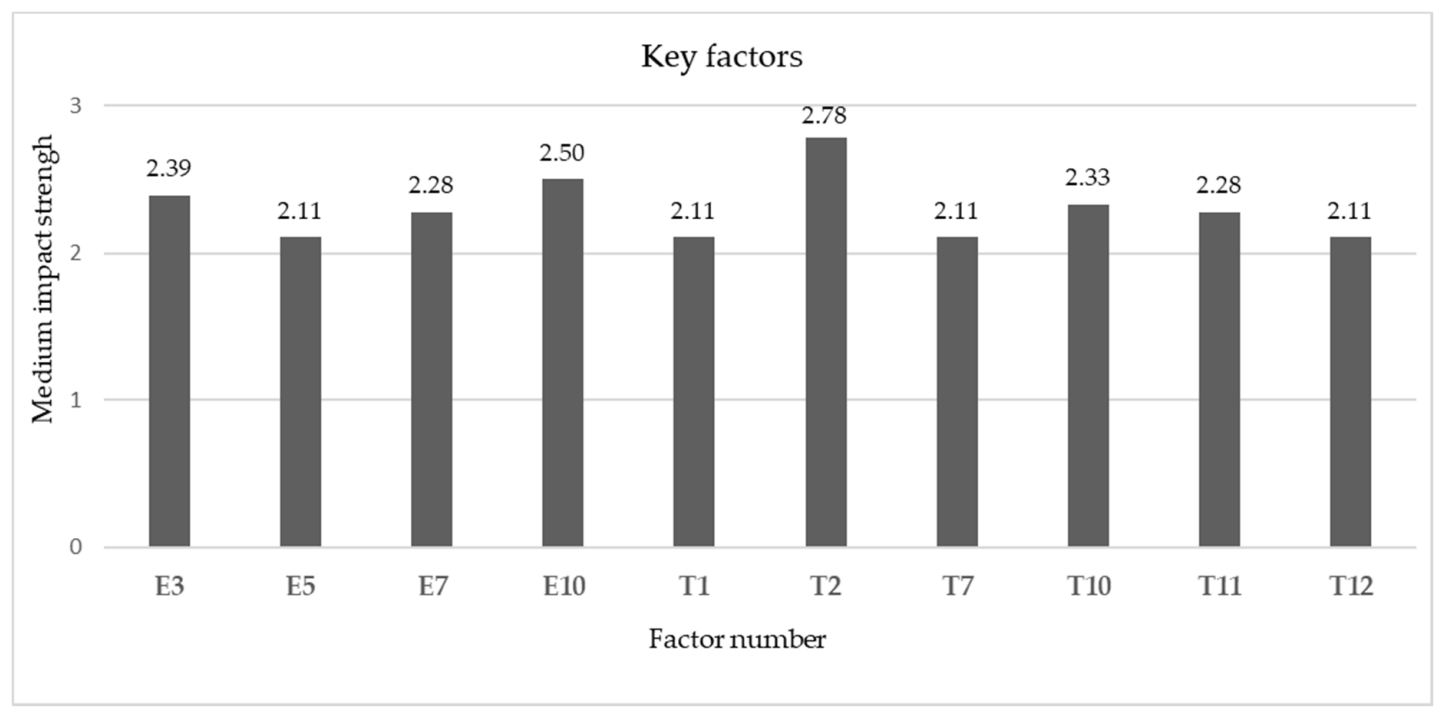

Figure 3. Key factors in the development of multimodal transport in the TRITIA area (2030 perspective). Source: Own elaboration.

The identified key factors include two areas: technological (6) and economic (4) factors. Among the two remaining groups of factors, no key determinants for the development of multimodal transport within the cross-border area were identified. Among the three factors with the highest impact strength-the experts included: the level of transport corridors development including multimodal infrastructure, internalisation of the external transport costs and state expenditures on the development of linear and nodal infrastructure of various transport branches.

\subsection{Identification, Verification, and Generation of New Projects Essential for the Development of Multimodal Transport within the Cross-Border Area}

This stage of the study resulted in the identification of 34 cross-border rail transport infrastructure projects, 25 projects for the modernisation and development of linear infrastructure in road transport and six projects for the modernisation and creation of new linear and nodal infrastructure in inland waterways. The analysis of the bottlenecks within the cross-border area under consideration allowed for generating 11 new railway projects, one project for the development of linear road transport infrastructure and one infrastructure project for the development of inland waterway transport.

\subsection{Identification of a Vision for the Development of Multimodal Transport within the Cross-Border Area}

According to the presented criteria described at this stage, four scenarios were defined (cf. Figure 4): Passive scenario, Reactive scenario, Preactive scenario and Proactive scenario.

The Passive scenario has been developed under conditions that hinder the development of multimodal transport in the TRITIA area. In such a scenario, each country within the cross-border area is assumed to implement its policies independently. There is no collaboration and the cooperation is at a low level. There are no developed communication and information flow systems or structural solutions. Simultaneously, in this scenario, it is assumed that only projects written in each country's policies are implemented and these are mainly infrastructure projects. In the TRITIA area, the development of transport, which has been observed for years, is practically entirely used by road transport. This has certain environmental repercussions, especially in terms of external costs: road damage, noise, deterioration of the environment, increased road safety risks. The undertaken initiatives are of an industry character and they concentrate on the development of particular branches of transport, and neither see nor create a systemic approach. This scenario is characterised by the lack of strategy for the development of multimodal transport within the cross-border areas. 


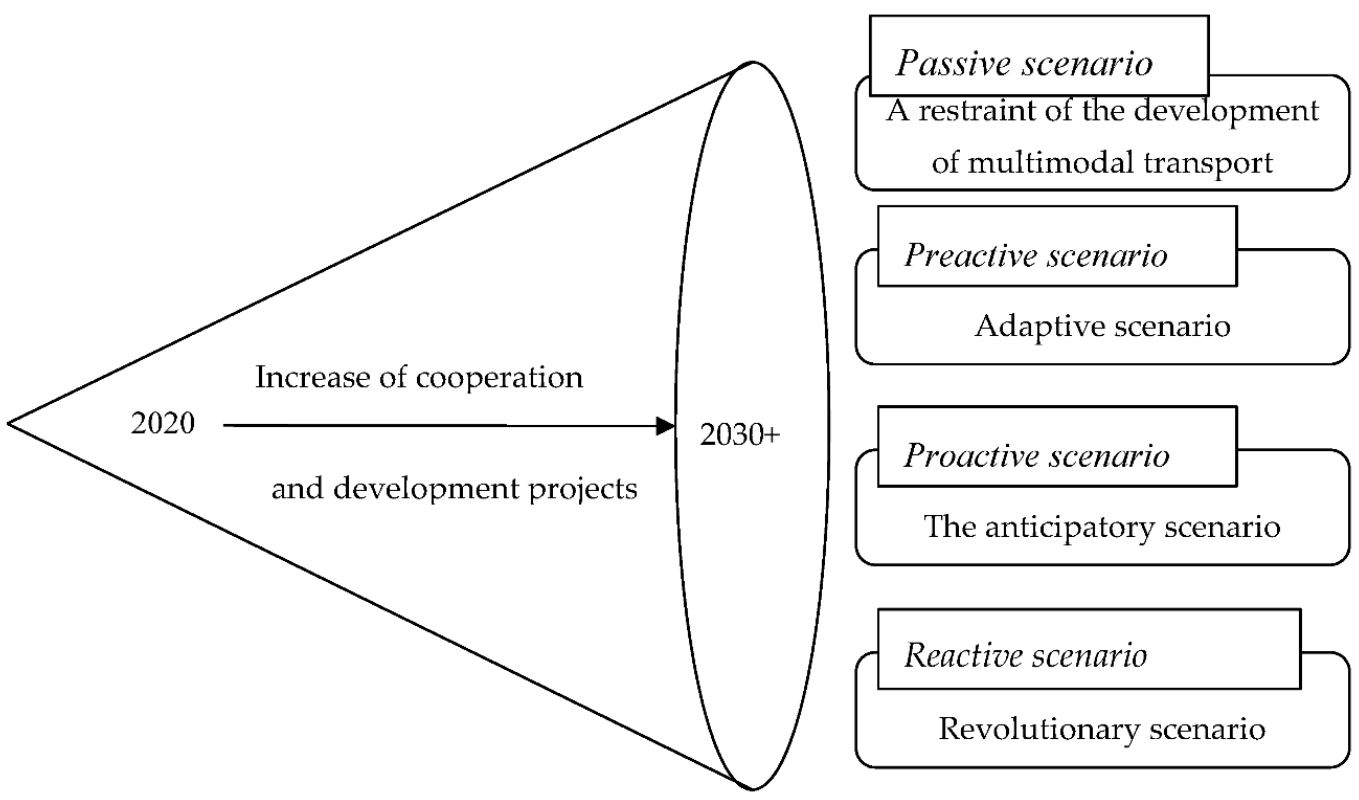

Figure 4. Four visions for the development of multimodal transport in the TRITIA area in the 2030 perspective. Source: Own elaboration.

The Preactive scenario is an adaptive scenario. It assumes a gradual response to emerging challenges in the area of cross-border transport. Therefore, a well-designed process of monitoring the transport system within the cross-border area, including monitoring technology development, and innovation, as well as changes in the factors determining flows in the freight transport network, is the basic reference. This concept assumes, on the one hand, a certain level of collaboration between countries in exchanging information and systematically supplementing databases. On the other hand, in order to implement such a vision, it is necessary to supplement the projects listed in the policies of individual countries with an organisational solution, providing a basis for collecting and processing data coming from individual countries of the TRITIA area. Such data should be independent of the country, but determining the system of cross-border freight transport. Moreover, the data should include information provided by individual multimodal freight stakeholders in the TRITIA cross-border area.

The Proactive scenario is an anticipatory approach to the development of multimodal freight transport in the TRITIA cross-border area. The proactive scenario is intended to act as a stimulus for the development of multimodal freight transport. The key direction is to take such initiatives, both infrastructural and organisational, which facilitate, support and direct the shift of freight flows from road to rail or inland waterway transport. These initiatives must be consistent across all countries and thus require a high level of cooperation, including an intensive exchange of information. The creation of changes in material flows must be accompanied by monitoring, which is also the basis for a Preactive scenario. The Proactive scenario, however, puts a stronger emphasis on taking action to initiate changes in the structure of flows, which requires network coordination. Consequently, there is a growing need to generate new projects with strong collaboration between all stakeholders and countries.

The Reactive scenario is a revolutionary solution. It imposes top-down solutions on stakeholders. The vast majority of them should comply with the solutions. These solutions are developed according to the concept of a dynamic system that is continuously developing and generating new solutions. Such a concept is based on a very strong degree of collaboration between countries and stakeholders, as well as a dynamic, regular generation of new solutions supported by projects. The monitoring and coordination are the basis of a complex dynamic system oriented at the continuous development of multimodal freight transport in the TRITIA cross-border area. The priority is given to projects focused on collaboration between countries to generate new solutions for multimodal freight transport. 


\subsection{Conceptual Work of the Analytical Team}

A. Characteristics of the scenarios as factors determining the development of multimodal transport within the cross-border area and the concept of embedding the scenarios in the criteria for cooperation and project support.

Table 5 presents a description of the different scenarios that determine the development of multimodal transport within the cross-border area. During the brainstorming session, the analytical team assigned each scenario the leading trends for key drivers of multimodal transport development in the TRITIA area (in the 2030 perspective).

Table 5. Scenario description of the selected factors and their trends.

\begin{tabular}{|c|c|c|c|c|c|}
\hline & & $\begin{array}{l}\text { Passive } \\
\text { Scenario }\end{array}$ & $\begin{array}{l}\text { Preactive } \\
\text { Scenario }\end{array}$ & $\begin{array}{l}\text { Proactive } \\
\text { Scenario }\end{array}$ & $\begin{array}{l}\text { Reactive } \\
\text { Scenario }\end{array}$ \\
\hline 1 & $\begin{array}{l}\text { The amount of state } \\
\text { expenditure on the } \\
\text { development of linear and } \\
\text { nodal infrastructure in } \\
\text { various branches of } \\
\text { transport }\end{array}$ & stabilisation & stabilisation & growth & growth \\
\hline 2 & $\begin{array}{l}\text { Price level of road } \\
\text { transport services }\end{array}$ & regress & stabilisation & growth & growth \\
\hline 3 & $\begin{array}{l}\text { Level of international } \\
\text { transit and trade }\end{array}$ & regress & stabilisation & growth & growth \\
\hline 4 & $\begin{array}{l}\text { Internalisation of external } \\
\text { transport costs }\end{array}$ & stabilisation & growth & growth & growth \\
\hline 5 & $\begin{array}{c}\text { Level of transport } \\
\text { integration in the TRITIA } \\
\text { area }\end{array}$ & stabilisation & stabilisation & growth & growth \\
\hline 6 & $\begin{array}{c}\text { Level of development of } \\
\text { transport corridors } \\
\text { including multimodal } \\
\text { infrastructure }\end{array}$ & regress & stabilisation & stabilisation & growth \\
\hline 7 & $\begin{array}{l}\text { Density of multimodal } \\
\text { terminals within the } \\
\text { cross-border area }\end{array}$ & stabilisation & stabilisation & stabilisation & growth \\
\hline 8 & $\begin{array}{l}\text { Level of separation of liner } \\
\text { infrastructure for freight } \\
\text { and passenger transport }\end{array}$ & stabilisation & stabilisation & stabilisation & growth \\
\hline 9 & $\begin{array}{c}\text { Level of use of modern } \\
\text { transshipment } \\
\text { technologies }\end{array}$ & stabilisation & stabilisation & growth & growth \\
\hline 10 & $\begin{array}{l}\text { Level of compliance of } \\
\text { intermodal loading units } \\
\text { with the regulations }\end{array}$ & stabilisation & stabilisation & growth & growth \\
\hline
\end{tabular}

Source: Own elaboration.

Scenario 1-Passive (trend: regress; average impact strength: -0.44)

Scenario 1 assumes the development of multimodal transport at its present level, which may result in the inability to achieve the objectives of the White Paper by 2030.

The implementation of the Passive scenario assumes the impossibility of increasing the expenditure of the TRITIA countries on the development of linear and nodal infrastructure in various branches of transport, which may impede producers and industry in the area from planning the investments. No new models will be created, allowing more goods to be transported by the most efficient means or a combination of such means of transport. Additionally, as prices in road transport decline, this will cause an increase in the use of lorries to transport goods over medium and long distances, without improving the energy efficiency of vehicles. As a result, there will be a decrease in international transit and trade between the TRITIA countries. In the absence of specific regulations on the internalisation of external costs of transport, there will be a distortion of free market competition among the different 
branches of transport as well as an imbalance in the distribution of transport between the different modes of transport, and there will be no measures to eliminate the negative effects of transport activities. Moreover, the scenario assumes the integration of transport in the TRITIA area at its present level, but this may lead to a lack of unification of the transport area, hamper the movement of goods, increase the cost of transport and cause imbalances in the development of European cross-border transport. As a consequence, the development of transport corridors, including multimodal infrastructure, may decrease. This will prevent the development of specially designed cross-border transport corridors that are optimised both in terms of energy use and emissions as well as in terms of minimising environmental impact and are attractive for their reliability, limited traffic congestion and low operating and administrative costs. There will be no change within the cross-border density of multimodal terminals, which will most likely make multimodal transport impossible. The separation of linear infrastructure for passenger and freight transport will be maintained at the present level, which will result in a lack of separation of intense passenger and freight traffic by allocating bypassing lines to freight traffic needs. Furthermore, there will be no increase in the use of modern transshipment technologies, which will increase the handling time of loading units and reduce the (already low) commercial speed of freight traffic. Under the Passive scenario, no legislative work will be undertaken to develop legal provisions adapted to the technologies of the different multimodal transport systems in the TRITIA area.

Scenario 2-Preactive (trend: growth; average impact strength: 0.85)

According to the Preactive scenario, the first factor, i.e., the amount of state expenditures on the development of linear and nodal infrastructure including various branches of transport, is predicted for this scenario at the existing, stable level. The current state expenditures focus on road and rail transport under the adopted development programmes. In this scenario, no reduction of these investments is expected-at the same time, no increase in infrastructure expenditures, especially non-road infrastructure, is planned in this scenario. As far as nodal infrastructure is concerned, it should be mentioned that, nowadays, its development results mainly from the initiative of companies operating in the transport and logistics sector, that are managers of terminals. It is also expected to maintain this state of affairs in this aspect. Assuming such a factor trend, its average impact on the development of multimodal cross-border transport amounts to 1.06. With regard to the second factor, i.e., the price level of services in road transport, a stabilisation trend is also assumed in order to realise the Preactive scenario. In this situation, the prices of road transport services do not change, which ensures that, as before, road transport will continue to be a competitive mode of transport on the market. This includes the price of transport in relation to other branches of transport. Hence, it can be concluded that, if the factor is stabilised, it will barely have a significant impact, either positive or negative, on the development of multimodal, cross-border transport (the impact identified amounts to 0.44). The level of transit and international trade is the third factor for which stabilisation is expected in the Preactive scenario. Under such circumstances, it is assumed that trade between Poland, Czech Republic and Slovakia is still at a relatively high level (nowadays, in the case of Poland, these are the main countries that implement the trade). Additionally, the level of transit to and from these countries remains the same (unchanged), which proves that Poland still does not fully exploit its central position in Europe, especially considering the trade with Eastern Europe and Asia both by rail and by sea. Again, the level of impact is very low and amounts to 0.56 . Another factor, i.e., the level of internalisation of external transport costs in the scenario, will have an upward trend. At the present time, road transport has very little internalisation of the external costs that it generates. In this case, however, the level of external costs in this branch is the highest. Considering this fact and the existing transport policy, this scenario assumes a gradual implementation of the 'polluter pays' principle, especially in the context of road transport. This trend in the scenario will have a definitely positive impact with a high impact level of 2.5. The Preactive scenario will also be implemented if the level of transport integration within the cross-border area under consideration is stabilised. All this results 
in a lack of new measures for building integrated transport systems, both in technical, regulatory and organisational contexts. The impact level is insignificant and amounts to 0.44 . The sixth factor, the level of development of transport corridors, including multimodal infrastructure in the scenario, will be at a stable level. This is due to the fact that the Core and Comprehensive TEN-T network will continue to be developed at a similar pace, with both rail, air and water infrastructure being included. The impact force is again insignificant at only 0.39. The Preactive scenario will also be implemented in a situation where the density of multimodal terminals will remain at a stable level. Consequently, no new multimodal network nodes are expected to be developed at the intersection of different branches of transport. This trend will generate a positive direction for the impact of a factor with a strength of 0.67. Another factor (level of separation of linear infrastructure for passenger and freight transport) in the scenario will also remain at a stable level. This is related to the fact that passenger trains will continue to have priority when performing transport tasks on the railways; at the same time, a large part of the linear infrastructure will be common to these two services. With regard to inland waterway transport, however, it is difficult to even identify infrastructure separation. The strength of the impact of the factor in such a situation has been estimated at 0.72 . The last factor is associated with the level of use of modern transshipment technologies. In the Preactive scenario, this factor will remain at the same level. It is mainly envisaged to use and develop vertical transshipment, with a small share of Ro-Ro and Ro-La transshipment. Such a situation will have positive impact of a factor with a level of 0.94 . In the last factor (level of compliance of intermodal loading units with road transport regulations), the scenario also expects stabilisation. At the same time, it is assumed that there will be no new solutions to change the existing regulations and allow for the use of a wider spectrum of intermodal loading units, which would improve the economic efficiency of transport. The impact of the factor is estimated at 0.78 .

To conclude, the Preactive scenario will be implemented if nine out of ten factors are stabilised. Only one factor related to the internalisation of external costs in the scenario will be in an upward trend. Following this trend in the Preactive scenario, the average impact strength of all ten factors will amount to 0.85 . This means that the factors can be considered as having little positive impact on the development of multimodal transport in the TRITIA cross-border area. However, this level is too low to prove a significant development of multimodal transport and satisfy the objectives of the White Paper.

Scenario 3-Proactive (trend: growth; average impact strength: 1.75)

The Proactive scenario assumes a high level of collaboration between stakeholders and the three countries: Poland, Czech Republic and Slovakia, as well as additional support for the development of multimodal transport, reaching further than the present national and regional policies of each country. Hence, in order to implement this scenario, it is necessary to assume an increase in the amount of state expenditures on the development of linear and nodal infrastructure in different branches of transport. The upward trend in expenditures is essential for the implementation of common transport objectives of all three countries and is intended to eliminate quality and capacity gaps between countries in the linear infrastructure of individual countries and to standardise technical parameters of the linear infrastructure. Experts have evaluated that the increase in expenditures on the development of linear infrastructure will boost the development of multimodal transport within the cross-border TRITIA area with an average impact level of 2.39. The increase in prices of services in road transport is a factor which affects the decisions of production and commercial enterprises as to the choice of transport branches and induces them to seek solutions in the area of rail or inland waterway transport. The experts have estimated that the increase in this factor has a positive impact on the development of multimodal transport in the TRITIA cross-border area with a force factor of 2.11. The Proactive scenario also assumes the increase in transit and trade between Poland, Czech Republic and Slovakia. This increase is an essential factor in recognising the importance of this area and expanding support for both infrastructural and organisational solutions and has been evaluated as supporting the development of 
multimodal transport with strength factor of 2.28. A major strength (average expert evaluation-2.5) supporting the development of multimodal transport in Scenario 3 is the increase in internalisation of external transport costs. This factor is currently at a minimum level, however, assuming that Scenario 3 is based on the initiation of measures to produce specific results, i.e., the development of multimodal transport within the cross-border area, the aim of shifting the economic consequences of transport to the originator is the right direction, which limits the role of road freight transport and increases the role of other branches of transport, which generate lower external costs. The increased integration of transport systems in the TRITIA area is consistent with Scenario 3. This factor, on the one hand, stimulates the development of multimodal freight transport within the cross-border area in general (average impact force of 2.11) but, on the other hand, affects the decisions on factor 1 and thereby increases investment in infrastructure of the different branches of transport. When analysing the level of development of the transport corridors including multimodal infrastructure in Scenario 3, there are no revolutionary changes in this area expected. A stable development (consistent with current trends) was considered sufficient to initiate changes in the development of multimodal transport in the TRITIA area. The experts assessed the stabilisation of this factor as marginally stimulating the development of multimodal transport (average impact strength of 0.39 ). The density of multimodal terminals is already satisfactory in the TRITIA area. That is why, Scenario 3 assumes stabilisation of this factor. The experts evaluated the stabilisation of the network density of multimodal terminals as slightly positively contributing to the development of multimodal transport in the TRITIA area (with an impact strength of 0.69 ). The stabilisation in this scenario is also characterised by the level of separation of linear infrastructure for freight and passenger transport. This separation of infrastructure would require revolutionary changes, which the Proactive scenario does not assume. The experts estimated that stabilisation in this factor has a slightly stimulating effect on the development of multimodal transport in the TRITIA area (average impact level of 0.72). The increase is characterised by both the degree of utilisation of the modern transshipment technologies (Ro-Ro, Lo-Lo, Ro-La) and also by the compliance of the intermodal loading units with road traffic regulations of various models. The first one has a positive impact with a force of 2.28 and the second one with a force of 2.11. Both factors have been recognised as events stimulating the development of intermodal transport and, furthermore, constituting an important basis for initiating changes in freight transport in the TRITIA area with a view to promoting multimodal transport solutions. The Proactive scenario is described by key factors with an average impact force of 1.75 . It can be concluded that this scenario will have a positive impact on the development of multimodal freight transport in the TRITIA cross-border area.

Scenario 4-Reactive (trend: growth; average impact strength: 2.3)

The Reactive scenario assumes an increase in all factors considered to be determinants of the development of multimodal transport in the TRITIA area. The experts assumed an increase in transport accessibility of the TRITIA cross-border area, with particular emphasis on the development of transport corridors based on multimodal infrastructure (impact strength of 2.78). There are two TEN-T core network corridors which run through the TRITIA area. It is the Baltic-Adriatic corridor connecting Polish seaports, through Czech Republic, Slovakia, Austria and Italian Adriatic ports. The second one is the Pan-European Transport Corridor III which connects Berlin-Dresden-Görlitz-Wrocław-Lviv-Kiev (it goes through the most important cities in the south of Poland). This corridor connects Western European countries with the Trans-Siberian Railway, through Odessa to the Red Sea. The New Silk Road connecting China with the Euroterminal in Sławków (Poland) is also significant. The development of transport corridors is motivated by the increase in international transit and trade (average impact force of 2.28), which makes the TRITIA area an essential node of multimodal transport. This is influenced by the rising price level of services in road transport (impact force-2.11), which encourages people to seek other branches of transport as an alternative but also economically viable. It is crucial to implement sustainable and innovative multimodal transport policies in the three countries under consideration, with particular emphasis on 
the TRITIA area. This will improve safety and reduce pollution and noise. It is a result of the increase in internalisation of external costs of transport (impact force of 2.5), which facilitates the development of rail and inland waterway transport. Along with the increase in the internalisation costs, the costs of road transport services are also increasing, which from a competitive point of view, improves the position of rail and waterborne transport. A sustainable policy, based on the increase in the volume of the state expenditures on the development of linear and nodal infrastructure in various branches of transport (average strength-2.0) will be based on the assumptions of the development of multimodal transport, under which the emphasis should be put on:

- activities promoting the reduction of the transport intensity of the economy, i.e., the demand for road-only freight transport;

- activities promoting better organisation of transport services (e.g., degree of use of logistics and intelligent technologies, especially traffic management technologies, organisation of last mile transport);

- modernisation and creation of new railways and waterways, including an increase in the separation of linear infrastructure for freight and passenger transport (strength-2.33), for better freight flows and capacity;

- reduction of train journey times and therefore increase the competitiveness of rail transport against other less environmentally friendly modes of transport;

- activities improving technical solutions for vehicles (powertrain and fuel) and infrastructure.

The increase of investment in the development of multimodal transport will be supported by close collaboration between authorities and companies at both regional and national level. This will ensure greater integration of transport in the TRITIA area (strength-2.11), but also the implementation of long-term projects enabling the area to be perceived as a key multimodal node for these transport corridors, which is emphasised by the increased level of compliance of intermodal loading units with road traffic regulations (2.11). Furthermore, consistent activities will allow the implementation of an optimal policy with regard to the density of multimodal terminals within the cross-border area (strength-2.11), which will lead to investments in trimodal infrastructure. However, it is necessary to apply innovative transshipment technologies (strength-2.28), which may be the result of joint projects with universities and research centres.

The Reactive scenario is characterised by key factors with an average impact force of 2.3. This scenario is definitely positive, which allows not only the planned projects to be implemented, but also aims reactively at creating a multimodal transport ecosystem in the TRITIA cross-border area.

B. Estimation of the probability of each scenario occurrence based on the probability defined for each trend determining the scenario

Table 6 presents the probability of each scenario occurrence based on the probability defined for each trend determining the scenario. Then, each of the scenarios determined by the factors are described. 
Table 6. Probability of scenario occurrence.

\begin{tabular}{|c|c|c|c|c|}
\hline Factor Name & Passive Scenario & Preactive Scenario & Proactive Scenario & Reactive Scenario \\
\hline $\begin{array}{l}\text { State expenditures on the } \\
\text { development of linear and } \\
\text { nodal infrastructure of various } \\
\text { transport branches }\end{array}$ & 0.31 & 0.31 & 0.51 & 0.51 \\
\hline $\begin{array}{l}\text { The price level of services in } \\
\text { the road transport }\end{array}$ & 0.06 & 0.62 & 0.32 & 0.32 \\
\hline $\begin{array}{l}\text { Level of international transit } \\
\text { and commercial exchange }\end{array}$ & 0.09 & 0.22 & 0.69 & 0.69 \\
\hline $\begin{array}{l}\text { Internalisation of the external } \\
\text { transport costs }\end{array}$ & 0.42 & 0.52 & 0.52 & 0.52 \\
\hline $\begin{array}{l}\text { The degree of transport } \\
\text { integration in the TRITIA area }\end{array}$ & 0.38 & 0.38 & 0.54 & 0.54 \\
\hline $\begin{array}{l}\text { The level of transport } \\
\text { corridors development } \\
\text { including multimodal } \\
\text { infrastructure }\end{array}$ & 0.04 & 0.73 & 0.73 & 0.23 \\
\hline $\begin{array}{l}\text { Density of multimodal } \\
\text { terminals within the } \\
\text { cross-border area }\end{array}$ & 0.62 & 0.62 & 0.62 & 0.35 \\
\hline $\begin{array}{l}\text { The level of separation of } \\
\text { linear infrastructure in setting } \\
\text { priorities for freight and } \\
\text { passenger transport }\end{array}$ & 0.56 & 0.56 & 0.56 & 0.38 \\
\hline $\begin{array}{l}\text { The degree of use of the } \\
\text { modern transshipment } \\
\text { technologies (Ro-Ro, Lo-Lo, } \\
\text { Ro-La) in freight and } \\
\text { passenger transport }\end{array}$ & 0.54 & 0.54 & 0.36 & 0.36 \\
\hline $\begin{array}{l}\text { The level of compliance of } \\
\text { intermodal loading units with } \\
\text { road traffic regulations of } \\
\text { various modes of transport }\end{array}$ & 0.57 & 0.57 & 0.36 & 0.36 \\
\hline
\end{tabular}

Source: Own elaboration.

\section{Scenario 1}

According to the expert opinion surveys, the average probability of Passive scenario occurrence is $36 \%$. This level can be considered as medium-realistic, however, it should not be completely excluded. The factor which, in the experts' opinion, achieved the highest probability (0.62) within the scope of a sustained trend at an unchanged level is the density of multimodal terminals within the cross-border areas. The factors with the lowest probability of an assumed trend occurrence were those related to the price level of road transport services and a factor including the level of transit and international trade. The other factors were given an average probability of occurrence for the trend identified at the previous stage.

\section{Scenario 2}

In the case of the Preactive scenario, the average probability of its implementation determined, based on the expert opinion surveys is $51 \%$. Considering the probability of occurrence of trends in the scenario for individual factors, it can be noticed that, by far, the lowest level $(0.22)$ is related to stabilisation in the level of transit and trade between the countries of the cross-border area under consideration. Similarly, the stabilisation trend for two subsequent factors is not correlated with high probability. These are: state expenditures on the development of linear and nodal infrastructure of various transport branches (0.31) and the degree of transport integration in the TRITIA area (0.38). For the remaining seven factors, the probability level is over $50 \%$. There are three factors with the highest level for the stabilisation trend in the scenario. These are: the level of transport corridors development including multimodal infrastructure (0.73), the price level of services in the road transport (0.62), and the density of multimodal terminals within the cross-border area (0.62). 
Scenario 3

The average probability for the Proactive scenario is $52 \%$. The most likely occurrences in this scenario are stabilisation of such factors as: the level of transport corridors development including multimodal infrastructure (0.73), and density of multimodal terminals within the cross-border areas (0.62). In this scenario, other likely occurrences (above 0.5 ) are also the increases in factors such as: state expenditures on the development of linear and nodal infrastructure of various transport branches (0.51), internalisation of the external transport costs $(0.52)$, and the degree of transport integration in the TRITIA area (0.54). The least likely, according to the experts, is an increase in factors such as: the price level of services in the road transport (0.32), the degree of utilisation of the modern transshipment technologies (Ro-Ro, Lo-Lo, Ro-La) (0.36) or the level of compliance of intermodal loading units with road traffic regulations of various modes of transport (0.36).

Scenario 4

Despite its revolutionary character, the Reactive scenario is characterised by a high probability- $43 \%$. This may suggest not only the need for significant changes, but also the willingness to implement joint actions enabling the development of multimodal transport in the TRITIA area. The most probable increase is the level of international transit and commercial exchange (0.69), and then, above $50 \%$ growth of the state expenditures on the development of linear and nodal infrastructure of various transport branches (0.51), internalisation of the external transport costs (0.52), and the degree of transport integration in the TRITIA area (0.54). The trends which limit the likelihood of this scenario to occur are mainly the increase of price level of services in the road transport, the level of transport corridors development including multimodal infrastructure, density of multimodal terminals within the cross-border area, the level of separation of linear infrastructure in setting priorities for freight and passenger transport, the degree of utilisation of the modern transshipment technologies (Ro-Ro, Lo-Lo, Ro-La) or the level of compliance of intermodal loading units with road traffic regulations of various modes of transport.

\section{Description of scenarios from the perspective of the implemented projects and cooperation}

The occurrence of the Passive scenario, which assumes the development of multimodal transport in the TRITIA cross-border area at the present level, requires the implementation of infrastructure projects included in the strategic documents of individual countries and regions. The implementation of the projects is assumed within the scope of the existing and newly created linear and nodal infrastructure of particular branches of transport. As far as road transport is concerned, five road projects are assumed to be implemented in the Polish cross-border area, including, among others, section E of the A1 motorway as part of the missing link between Czestochowa and Tuszyn, and the S1 expressway between Pyrzowice and Bielsko Biała, which are part of the European road transport corridor E75 'Gdańsk-Brno/Bratislava-Vienna'. They are part of the Trans-European Transport Network connecting the countries of the Baltic Sea basin with the countries of Southern Europe and located within the TEN-T Priority axis Project 25. The remaining projects are located on the list of projects for the next programme period, however, the implementation is to take place by 2030. Eleven projects in the Slovakian cross-border area are planned for implementation in the scope of road infrastructure modernisation. An important project in this context is an investment project directly affecting the development of multimodal transport concerning the access to the existing intermodal terminal in Žilina. At present, road transport is prevailing in the freight exchange between Poland and Slovakia, and the implementation of cross-border road projects, to a greater extent, may contribute to the increase in the flow of vehicle transport. This situation, unfortunately, poses a serious barrier to the development of multimodal transport in this cross-border area, to a significant extent. Meanwhile, in the Czech cross-border area, there are eight projects planned in the field of road infrastructure development. One of the main road projects is the project concerning the first and second stage of construction of the D48 Frýdek-Místek ring road, which aims mainly at shifting transit traffic from the 
city centre. Moreover, in the Moravian-Silesian Region, the D48 motorway is an important traffic artery in the west-eastern direction. The road connects the southern part of the Moravian-Silesian Region with Central Moravia and Poland. Another project involves connecting the D48 national road with D56. This project, within the Moravian-Silesian Region D56/I/56, forms an important artery from the north to the south, which connects Ostrava with Slovakia through Horní Bečva-Makov or Bílá-Klokočov.

There are eleven projects planned for the modernisation and development of rail transport infrastructure in the Polish cross-border area, eight of which are high-priority projects. One of the most important projects is the modernisation of the E65 railway line, which is a transport line of international importance established under the European Agreement on Main International Railway Lines (AGC) and under the European Agreement on Main International Combined Transport Lines and Associated Facilities (AGTC).

The E65 arterial line belongs to the Pan-European Transport Corridor VI connecting the Baltic States with the countries of the Adriatic Sea and the Balkans. There are nine railway projects that are relevant for the Slovak cross-border area. However, it is worth mentioning that freight rail transport between Poland and Slovakia operates-due to geographical conditions (the Beskid Mountains-Jablunkovska Pass)—through Czech Republic. The existing railway connection Čadca-Zwardoń and further towards Bielsko-Biała is currently of marginal significance for freight traffic. Even the comprehensive modernisation of railway lines will not lead to the development of multimodal transport due to the existing technical conditions (slope of the tracks). Nevertheless, it should be highlighted that railway investments in the Silesia region-dedicated to traffic from/to Slovakia (modernisation works on railway line 139) will allow for indicating the technical conditions for shifting road transport to other branches of transport-as required by the White Paper. In the Czech cross-border area, thirteen infrastructure projects are planned to be implemented within the scope of rail transport, ten of which are of priority importance for the transit traffic through Czech Republic. One of these projects concerns the modernisation of the Ostrava node with regard to the possibility of separating the linear infrastructure dedicated to the implementation of freight traffic intended for cross-border freight transport.

It should be emphasised, however, that waterways in the TRITIA cross-border area have great potential for international links and are considered for inclusion into the Trans-European Transport Network. For this purpose, the Act on Ratification of the European Agreement on Main Inland Waterways of International Importance (AGN) has recently come into effect in Poland. The AGN Convention obliges Poland to adapt its main waterways to at least Class IV navigability. The agreement also specifies ten locations of inland ports of international importance. Currently, waterways in Poland, with the exception of short sections on the Lower Oder, do not comply with the minimum international navigability requirements stipulated by the AGN Convention. Due to the next TEN-T revision in 2023 , it is necessary to develop and adopt programmes for rebuilding waterways to be included in the network.

The Preactive scenario assumes the implementation of two groups of projects. The first group includes a number of formulated infrastructure projects geographically located in the TRITIA area. These projects have been written down in the strategic documents of individual countries. They concern three main branches of transport that play (or may play in the future) a superior role in the implementation of freight transport in the given cross-border area. It should be mentioned that these are the same projects that are assigned to the Passive scenario. The highest priority, among the infrastructure projects, for the implementation of the Preactive scenario, is assigned to projects related to rail and inland waterway transport, while road projects have mostly complementary status, which is the result of the role of road transport in multimodal transport.

The second very crucial project in the implementation of the Preactive scenario is the establishment and functioning of the Technology Observatory in the TRITIA area: Transport and Logistics. The main objective of the Technology Observatory will be to identify and monitor technological and market trends in the development of multimodal transport within this cross-border area. The first group of tasks of the Technology Observatory will be focused on the analysis of the existing multimodal 
transport system in the TRITIA area, together with the indication of the transport and logistics potential of the region in the development of multimodal transport. A lot of attention within the framework of the activities of the Technology Observatory is intended to be given to the monitoring of the needs of the entities related to multimodal transport in the region. Moreover, special attention will be paid to the relations established between the participants of the multimodal transport network, both in the context of their monitoring and supporting, and taking action to establish cooperation aimed at exploiting the region's potential for developing multimodal transport. The second group of tasks of the Technology Observatory will concern the monitoring of the implementation of the multimodal freight transport development strategy. The construction and adoption of the strategy itself is an important task, which results, among other things, from the fact that, currently, there are no separate strategic assumptions for freight transport (including multimodal transport) in the TRITIA area, which is due to a greater focus on the transport of people than freight. The third group of activities of the Technology Observatory will concern the collection and processing of knowledge on emerging technological, infrastructural and organisational solutions that can remove barriers to the development of multimodal transport in practice. Furthermore, it will aim at indicating the possibilities of applying these solutions in multimodal transport of the analysed cross-border area, bearing in mind its potential, but also its limitations. The last group of tasks will be related to supporting and following the development of multimodal transport in the region and making regular evaluations of the undertaken activities for the development of multimodal transport.

The Proactive scenario assumes a holistic approach to stimulate the development of multimodal transport within the cross-border area with both infrastructure and organisational projects. The network of multimodal transport within the cross-border area is a particularly complex system as it has to take into account the stakeholders of different branches of transport and several countries. Initiation of changes related to the development of multimodal freight transport within the cross-border area, which is the essence of the Proactive scenario, requires organisational solutions directed not only at monitoring, collecting and exchanging knowledge about flows, but also at synchronising those flows and connecting all actors of the network into a common comprehensive knowledge management system, together with taking joint initiatives of all countries and all stakeholders for the development of multimodal transport. The analysis of the key factors in this scenario has shown the relevance not only of macroeconomic factors such as the level of trade and transit, but also of taking steps to unify transport policies and sustainable development of transport and transshipment technologies in all partner countries. These challenges form the basis for the concept of a coordinator model in the multimodal freight network in the TRITIA cross-border area proposed by the authors. The coordinator under this concept is understood as an organisational unit that is established at the TRITIA association and has the following functions:

- Processing the knowledge about material flows in the TRITIA area in different branches of transport and sharing this knowledge with stakeholders,

- Stimulating multimodal transport development solutions and projects that support innovation and sustainability,

- Initiating projects to reduce transport time using non-road branches of transport, and to reduce delays and improve the flexibility of material flows by these branches of transport,

- Modelling material flows within the cross-border area based on knowledge resources and designing new development scenarios in accordance with changes in the environment of the multimodal freight transport network in the TRITIA area.

The coordinator model cannot function properly without the knowledge management concept within the multimodal transport network. This comprehensive concept requires a systematic monitoring of the network and the collection of information and data that the Logistics Observatory gathers. The coordinator must take into account the changing environment of a multimodal transport network in a cross-border area as well as changes within the network itself. The coordinator develops scenarios 
and models' freight flows based on that data and knowledge of the effectiveness and efficiency of specific solutions, both strategic and operational, to support the decisions of the different multimodal transport stakeholders.

The Proactive scenario also includes highly significant infrastructure investments to address the gaps in the sustainable development of multimodal freight transport in the TRITIA area identified by the coordinator. The Proactive scenario assumes that these investments should be a consequence of developing the key competences of individual regions. Trimodal logistics centres are essential for the cohesion of multimodal freight transport development. In this scenario, on the Polish side, it is assumed that the development of competences through supporting the existing key nodes will be achieved-The Silesian Logistics Centre and Euroterminal Sławków. Infrastructure investments concerning these nodes are considered a priority. On the Czech side, it is indicated that the Logistics Centre in Ostrava will be such a key investment. Slovakia identifies cross-border solutions in rail transport as key investments. All three countries agree on evolutionary systemic solutions to activate inland waterway transport, especially in the area of the Silesian Canal, which is expected to become a natural catalyst for the development of new multimodal nodes, both industrial and general.

The Reactive scenario assumes the creation and development of a multimodal transport ecosystem. It is a multi-level system, which depends on the activity of the existing and new entities, open to experimenting and creating new ideas and concepts, looking for key areas and values that will differentiate the TRITIA area as key in the development of multimodal transport.

This ecosystem should develop standards (technical, technological), norms and know-how that are recognised and applied by multimodal transport organisations in the TRITIA area and other areas as well. The diffusion of implementation of standards in the ecosystem leads to the adoption of these standards by subsequent organisations. This allows for the joint development of key skills, which will constitute the basis for building a competitive advantage for the ecosystem as a whole and its individual participants. By using these skills, strategic directions are set for the whole ecosystem based on the principles of co-evolution. Consequently, it can be assumed that the multimodal transport ecosystem of the TRITIA area should be characterised by an internal structure with both vertical and horizontal relationships. Among the ecosystem participants, there are companies from the three branches of transport, scientific centres, business environment institutions, national, regional and local authorities, that play a key role in the implementation of a coherent strategy.

The basis for ecosystem development is the implementation of infrastructural and organisational projects planned in the previous scenarios. Additionally, the implementation of infrastructural projects focused on inland navigation is required. The revolutionary approach to the development of freight transport in the TRITIA cross-border area is based on the assumption of a strong development of water corridors: D-O-E and the Silesian Canal. The Danube-Oder-Elbe (D-O-E) water corridor is one of the largest projects for the development of European transport infrastructure. Not only is it the missing link of the interconnected European system of inland waterways, but it is also a multipurpose water project of great importance for Poland, Czech Republic, Slovakia and the whole of Europe. The Silesian Canal, however, as a planned waterway connecting the Oder River with the Vistula River and the Upper Silesian Industrial District and Rybnik Coal Area with Cracow, should become a critical point for infrastructure projects in this scenario. It is intended not only to be an important part of the entire water system in Poland, but also to provide an opportunity to connect the Vistula with the Danube in the future.

Further projects related to the nodal infrastructure will depend on the decision of the stakeholders (including primarily national and local authorities). Apart from the Silesian Logistics Centre, Euroterminal Sławków and the Logistics Centre in Ostrava, there are also plans to build: trimodal centre in Žilina, Krzyżanowice transshipment terminal, Racibórz Logistics Centre, Container terminal Gorzyce-Verřnovice, Rybnik inland port and transshipment terminal, Żory transshipment terminal, Bieruń transshipment terminal, AZOTY specialist transshipment terminal, and Kędzierzyn Koźle container terminal. Clearly, not all logistics terminals or centres will be launched in the years 2020-2030, 
but decisions in this respect should be the result of common solutions proposed by the Logistics Observatory and the coordinator of the multimodal freight network for the TRITIA cross-border area. The joint decisions should concern multimodal transport as a whole, which means that linear infrastructure, especially rail, should be considered as an equally important priority for the future multimodal transport vision (2030) in the TRITIA area.

\section{Discussion}

The method adopted to identify the key factors in accordance with the Pareto principle $(20 \%$ of the factors generate $80 \%$ of the effects) has led to the adoption of a borderline average value of the impact force at the level of 2.11. It should be mentioned that in the case of neither of the key factors, the highest impact force was not to hinder the development of multimodal transport within the cross-border area. As factors with the highest impact force, the experts identified: the level of transport corridors development including multimodal infrastructure (impact force of 2.78) and internalisation of the external transport costs (2.50). The highest values of these factors are not surprising. The former clearly highlights the importance of multimodal transport infrastructure for the development of freight transport within the cross-border area. Moreover, it emphasises the need to integrate this infrastructure into the designation of international transport corridors. Therefore, there is a need for collaboration between cross-border countries and regions, in order, among other things, to create integrated, uniform and coherent infrastructure. A high rating of the second factor may result from the provisions of the White Paper and frequent emphasis on the need to implement the 'polluter pays' principle in transport. This probably also results from the fact that experts have noticed the current disproportions between particular branches of transport in the context of covering the external costs of transport generated by them. Road transport, which is an infamous leader in the external costs it generates, at the same time internalises them to the least extent. Efforts to balance the internalisation of external costs generated by individual branches of transport will influence the prices of services in the transport market, which is one of the important drivers of demand and its structure on the market.

The identified critical factors represent two main environmental spheres-economic and technological. Under the first sphere, four factors were identified, while under the second sphere, six factors were identified. Comparing these two groups of factors, a balance between them is apparent-the average impact strength for economic factors is 2.32 and is slightly higher than the average for the technological sphere factors (2.29). Hence, it is necessary to stress the importance of both economic and technological aspects in the development of multimodal transport. Clearly, among all ten factors, issues related to both linear and nodal infrastructure as well as issues related to the transshipment of freight units are the most pronounced. However, there is a lack of representatives of both socio-cultural and environmental, as well as political and legal spheres among the key factors. In the case of the first sphere, the average impact force for only three of the eight factors identified exceeded 1.5 (level 2 was not exceeded by any factor). It may be assumed that this sphere would be more relevant for analyses concerning passenger rather than freight transport. However, the absence of political and legal factors is of particular concern. It can be speculated that this is related to the treatment of transport policy guidelines and legal aspects as an area where the consequences are visible in all other spheres of the environment and the analysed factors. It can be concluded that they shape other spheres of the environment.

The analytical team identified four visions, which refer to the model approach presented by Godet (1993). The characteristics of the individual scenarios clearly indicated the differences especially between scenarios 2 and 3, which differs from the results of Godet (1993), who indicated the strongest differences between scenarios 3 and 4 , while emphasising that the differences between scenarios 2 and 3 are subtle and often difficult to demonstrate. The adaptive and anticipatory scenarios for the development of multimodal freight transport in the TRITIA cross-border area show significant differences already at the level of characteristics between two key criteria: the extent of cooperation and support for infrastructure and organisational projects. The initiation of activities focused on the 
development of multimodal transport within the cross-border area requires the involvement of all participants in the process, i.e., all countries (Poland, Czech Republic and Slovakia) as well as various stakeholders. In this case, all operators in a multimodal transport network must have a common vision, accept it and understand their role in achieving the ultimate goal of the whole network. Therefore, the scope of cooperation is much larger than in the adaptive scenario. Moreover, stimulating the development of multimodal transport within the cross-border area requires complex organisational solutions and infrastructure investments in all countries. While between Scenarios 1 and 2 as well as between Scenarios 2 and 3, there is an increase in the scope of cooperation but also an increase in the scope of projects supporting the development of multimodal transport, there is not so much increase in the scope of collaboration between Scenarios 3 and 4, but there is still a strong need for new organisational solutions supported by projects. The scenarios in the criteria of cooperation and project support are presented in Figure 5.

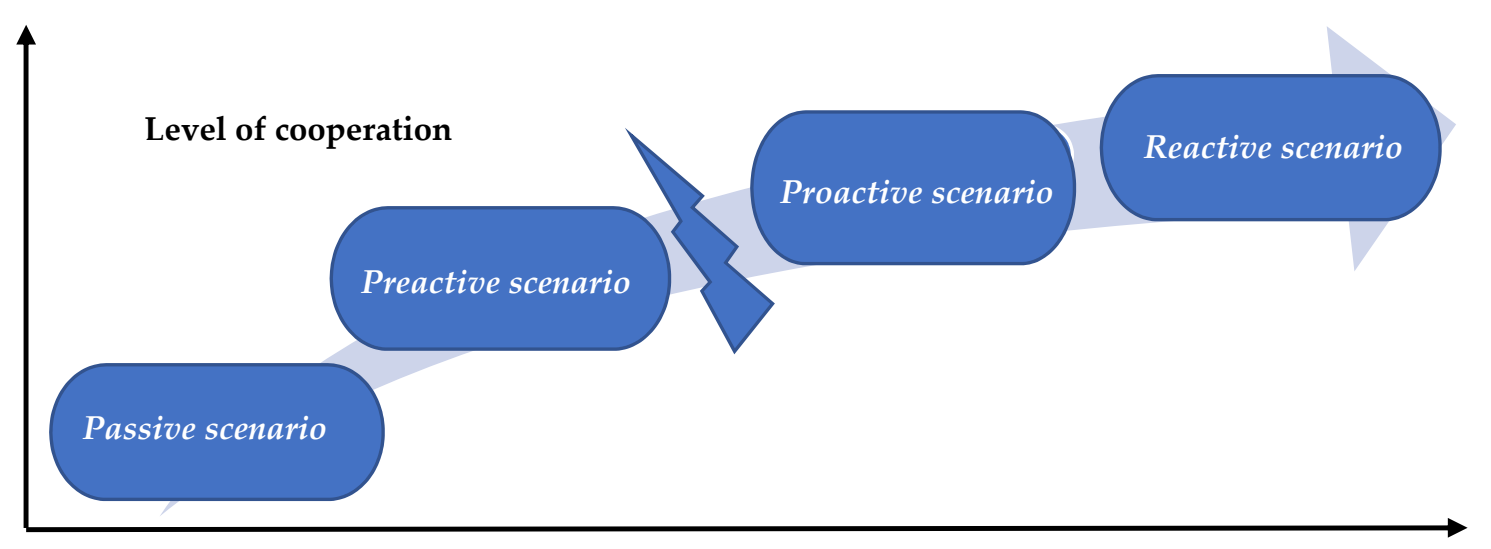

Project support

Figure 5. The scenarios in the criteria of cooperation and project support. Source: Own elaboration.

The revolutionary character of Scenario 4 requires substantial structural and organisational changes, but also projects that go beyond the evolutionary development of the region so far; however, it is-like Scenario 3-based on a vision that involves all stakeholders of the multimodal transport network in the TRITIA cross-border area.

The two criteria-the scope of project support and the scope of cooperation-proved to be strongly determined by the identified scenarios, including key factors for the development of multimodal transport within the cross-border area. In the final results, it can be concluded that these two criteria are superior to the key factors for which the scenarios were characterised by trends at the subsequent stages. The trends describing the individual scenarios vary from a predominantly stable scenario (seven factors), with a small number of decreasing trends (three factors) in the Passive scenario, to a predominantly stable trend (as many as nine factors per one factor in the growth phase) in the Preactive scenario, to a scenario with a significant predominance of increasing trends (seven factors per three factors in the stabilisation phase) in the Proactive scenario, to a Reactive scenario, which is only described using the increasing trends. These correlations strongly confirm the differences between the adaptive and anticipatory scenarios. The trend pattern of the individual scenarios determines the differences in the strength of impact of the individual scenarios on the development of multimodal transport within the cross-border area. Once again, the smallest difference can be observed between Scenarios 3 and 4 . However, when analysing the differences in the probability of the individual scenarios, it can be observed that the two scenarios, which vary strongly in terms of the strength of the impact on the development of multimodal transport, as well as the extent of cooperation and the extent of project support, have similar probability.

The comparison of individual probabilities of a given scenario are shown in Figure 6. 


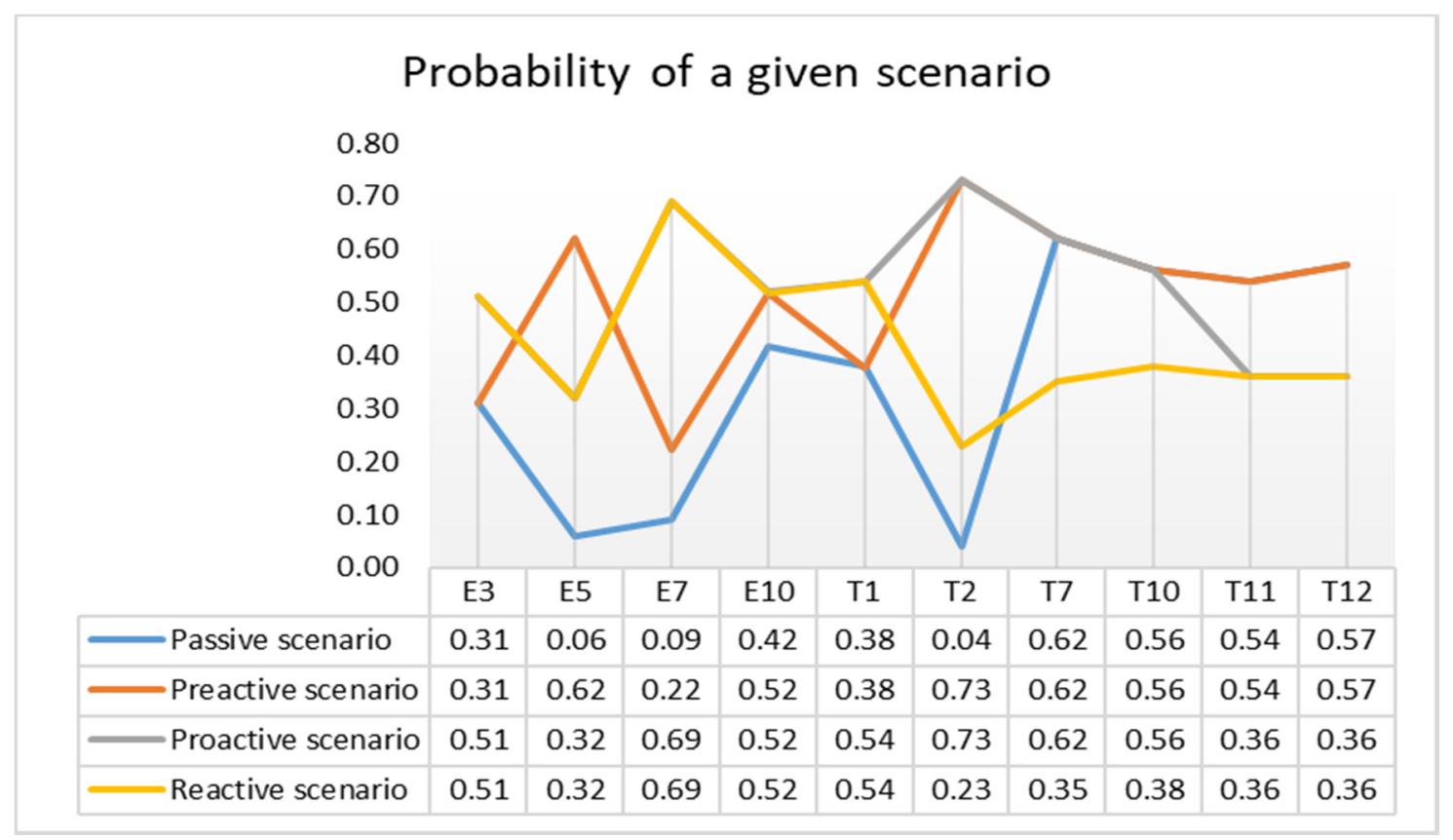

Figure 6. Probability of given scenarios. Source: Own elaboration.

The above in Figure 6 implies that both adaptive and anticipatory scenarios are highly probable, and the factor which will determine this the most is the support for infrastructure projects (especially within the linear infrastructure) and organisational projects. Organisational projects assume a high level of collaboration and solutions connecting all three countries through the observatory and coordinator model. Furthermore, attention should be paid to the relatively high probability of Scenario 4 (exceeding $40 \%$ ). The experts were optimistic about the development trends in multimodal transport in the TRITIA area, which may also be associated with large needs identified by experts in this area.

Each of the scenarios of multimodal transport development presented by the analytical team assumes implementation of infrastructural and organisational projects. The Passive scenario assumes implementation primarily of infrastructural projects included in strategic documents of regions and cross-border countries. They refer to three main branches of transport essential for freight transport within the cross-border area under consideration. It should also be emphasised that the implementation of these projects should be based on collaboration that clearly defines the mutual interests and needs of the regions belonging to the TRITIA area. The Preactive scenario, apart from the implementation of infrastructure projects included in the Passive scenario, assumes the establishment and functioning of the Technology Observatory in the TRITIA area: Transport and Logistics. This type of project is of an organisational nature and would be the first project of such type, which would allow for effective and efficient implementation of joint, cross-border development activities. There is still a lack of appropriate coherence between cross-border and regional as well as sectoral programmes, which should be complementary and synergistic. The project to establish the Technology Observatory is clearly a necessary project to be implemented in a Preactive scenario. The Proactive scenario assumes the necessity to implement both infrastructural and organisational projects oriented towards the development of multimodal transport. Apart from the projects necessary for the Passive and Preactive scenarios, the Proactive scenario requires activities aimed at launching the project of a coordinator model in the multimodal freight network in the TRITIA cross-border area. It should be emphasised here that the implementation of the Proactive scenario will be an innovative approach to cross-border collaboration, which may result in more efficient and effective implementation of TRITIA freight flows. The most advanced concept of project implementation assumes the reactive scenario as a developed ecosystem of multimodal transport in the analysed cross-border area. It involves, apart from the implementation of infrastructural and organisational projects planned in the previous scenarios, 
increasing the functionality, efficiency, complementarity, cooperation and regulation of multimodal freight transport, which is related to the dynamic development of linear and nodal infrastructure, including projects that exceed the framework of the existing evolutionary development of the TRITIA cross-border area. However, considering the time limits (2030) and budget limits, the variant which can be recommended to policymakers for the innovative transport policy is Variant 3-a Proactive one. From this perspective, the "as is" and "to be" research would be necessary in the context of the implemented projects and expected strategic results coming from the adopted strategies. A strategy of the multimodal transport development for the TRITIA area is currently developed in the TRANS TRITIA project. Once the developed strategy is approved by the implementing unit, it will be possible to use the "as is" and "to be" analysis [101,102].

\section{Conclusions}

Europe is strongly committed to increasing alternative modes of transport compared to road. It is also important that statistics clearly show the potential for multimodal transport to develop. However, this trend is not entirely clear, especially when it comes to the scope of change. Hence, from the future perspective, it is extremely difficult to accurately plan the future dynamics of freight flows and even more problematic to identify priority investments for an optimal development of multimodal transport. In order to meet the combined challenges of complexity and uncertainty, the authors proposed to develop four visions for the future, which, based on the analysis of key factors, allowed to present four scenarios for the future development of multimodal transport by 2030. The approach presented is not of a classical approach, but combines different concepts. Two of them (Passive and Proactive scenarios) are focused on the recognition of the current transport development policy with an indication of current market observation. These 'safe' scenarios, however, are unable to ensure the implementation of the objectives stated in the White Paper. Although there is a growing uncertainty in emerging crisis situations (e.g., a pandemic threat), Proactive and Reactive scenarios determine the success of multimodal transport development. In other words, regardless of the surrounding conditions, these scenarios have the potential to allow the cross-border area under consideration to operate optimally, while reducing congestion, emissions and accidents.

In order to ensure further dynamic growth of multimodal transport in the TRITIA area, it is essential both to create favourable conditions for cooperation and to undertake joint projects in the area of infrastructure development and organisational support. The challenge for the analysed area is primarily to remove the backlog in the expansion, modernisation and revitalisation of transport infrastructure and to connect the infrastructure of the most significant nodes of the European transport network, including the TEN-T core network corridors. A coherent network of high standard motorways, expressways and railways together with a developed network of inland waterways will result in the full utilisation of the potential of the three countries' economies under consideration. It should be kept in mind that the creation of a coherent multimodal transport ecosystem requires both the dynamic development of the missing elements of the transport infrastructure and the improvement of the infrastructure quality, its technical standards and the implementation of solutions integrating the transport networks.

The research conducted in the article allowed for developing four visions of multimodal transport development by 2030. The presented analyses allowed for identifying new research gaps, which constitute grounds for further research. The first identified research gap is the need to investigate the role of stakeholders in the implementation of individual scenarios. This relationship has a two-way character, i.e., what impact on the implementation of the scenarios the various stakeholder groups have and, on the other hand, how the scenarios affect stakeholder development. Such research, conducted by the authors of the paper, will certainly enrich the knowledge on the future development of multimodal transport in similar areas. The second gap concerns the aspect of inter-organisational collaboration between stakeholders in the multimodal transport network within the cross-border area. The conducted research indicates differences between cooperation and collaboration, which is 
a crucial background for future implementation of the vision of multimodal transport development within the cross-border area. However, it should be emphasised that the implementation of Proactive and Reactive scenarios will only occur if the future direction of multimodal transport is based on collaboration. This is a particular issue that has been discussed in the framework of regional and cross-border policymaking concerning multimodal transport.

The research and presented scenarios can be an important guideline for the policymakers in terms of defining the priorities of the multimodal transport development in the researched regions and countries. However, the multimodal transport development is determined not only by the policymakers, but also by other stakeholders. That is why, a separate evaluation of the stakeholders in terms of the proposed scenarios seems essential. Considering the length of this topic, the authors intend to examine this problem in detail and present it in a separate paper.

Author Contributions: Conceptualisation, M.K., K.D., E.P. and L.K.; methodology, M.K., K.D., E.P. and L.K.; software, M.K., K.D., E.P. and L.K.; validation, M.K., K.D., E.P. and L.K.; formal analysis, M.K., K.D., E.P. and L.K.; investigation, M.K., K.D., E.P. and L.K.; resources, M.K., K.D., E.P. and L.K.; data curation, M.K., K.D., E.P. and L.K.; writing-original draft preparation, M.K., K.D., E.P. and L.K.; writing—review and editing, M.K., K.D., E.P. and L.K.; visualisation, M.K., K.D., E.P. and L.K. All authors have read and agreed to the published version of the manuscript.

Funding: The research presented in the paper was supported by statutory work 13/040/BK_20/0085 carried out at the Faculty of Organisation and Management, Silesian University of Technology.

Conflicts of Interest: The authors declare no conflict of interest.

\section{References}

1. Walancik, M.; Kurowska-Pysz, J. Cross-border cooperation of local governments in the field of safety in Polish-Slovak projects. Theoretical approaches and a case study. J. Def. Resour. Manag. 2015, 6, 45-54.

2. Guo, R. Studying Borders. Evaluating Border Effects. Cross-Border Resource Management, 3rd ed.; Elsevier: Amsterdam, The Netherlands, 2018.

3. Castanho, R.A.; Cabezas, J.; Fernández-Pozo, L. Territorial Planning and Development Tools in Transboundary Areas. Study Case of the OTALEX-C Space. In Conference Paper, Proceedings of the Institute of Geography and Spatial Planning-University of Lisbon E International Journal of E-Planning Research, Lisbon, Portugal, 31 March-1 April 2016; Institute of Geography and Spatial Planning, University of Lisbon: Lisbon, Portugal, 2016.

4. Castanho, R.A.; Loures, L.; Cabezas, J.; Fernández-Pozo, L. Cross-Border Cooperation (CBC) in Southern Europe-An Iberian Case Study. The Eurocity ElvasBadajoz. Sustainability 2017, 9, 360. [CrossRef]

5. Castanho, R.A.; Cabezas, J.; Fernández-Pozo, L.; Vulevic, A.; Aranjo Gómez, J.; Mart n Gallardo, J.; Loures, L. Common Regional Development Strategies on Iberian Territory. Envisioning New Horizons: Post 2020. In Enfo Uesen la Planificación Territorial y Urban Stica; Thomson Reuteurs Aranzadi: Pamplona, Spain, 2018.

6. Bufon, M.; Minghi, J.; Paasi, A. (Eds.) The New European Frontiers: Social and Spatial (Re) Integration Issues in Multicultural and Border Regions; Cambridge Scholars Publishing: Cambridge, UK, 2014.

7. Balogh, P.; Pete, M. Bridging the Gap: Cross-border Integration in the Slovak-Hungarian Borderland around Štúrovo-Esztergom. J. Borderl. Stud. 2018, 33, 605-622. [CrossRef]

8. Telle, S.; Svensson, S. An organizational ecology approach to EGTC creation in East Central Europe. Reg. Fed. Stud. 2020, 30, 47-71. [CrossRef]

9. Böhm, H.; Opioła, W. Czech-Polish Cross-Border (Non) Cooperation in the Field of the Labor Market: Why Does It Seem to Be Un-De-Bordered? Sustainability 2019, 11, 2855. [CrossRef]

10. Wasiluk, A. Companies' Understanding of Trans-border Cooperation: An Empirical Study in Poland and Republic of Belarus. In Eurasian Business Perspectives, Eurasian Studies in Business and Economics; Bilgin Mehmet Huseyin, B.M., Hakan, D., Ender, D., Ugur, C., Eds.; Springer: Berlin/Heidelberg, Germany, 2019; Volume 10, pp. 309-324.

11. Lundén, T. Border Regions and Cross-Border Cooperation in Europe. A Theoretical and Historical Approach. In European Territorial Cooperation. Theoretical and Empirical Approaches to the Process and Impacts of Cross-Border and Transnational Cooperation in Europe; Medeiros, E., Ed.; Springer: Berlin/Heidelberg, Germany, 2018; pp. 97-113.

12. Regulation No 1315/2013 of the European Parliament and of the Council; EU: Brussels, Belgium, 2013. 
13. Regulation No 1316/2013 of the European Parliament and of the Council; EU: Brussels, Belgium, 2013.

14. Bodewig, K. Baltic_Adriatic. Third Work Plan of the European Coordinator; European Commission: Brussels, Belgium, 2018.

15. White Paper. Roadmap to a Single European Transport Area-Towards a Competitive and Resource Efficient Transport System; COM (2011); European Environment Agency: Brussels, Belgium, 2011; p. 144.

16. Kozerska, M. Transport intermodalny w Polsce-Szanse i bariery rozwoju. Logistyka 2014, 3, 3200-3205.

17. Dohn, K.; Knop, L.; Kramarz, M.; Przybylska, E. Transport Intermodalny w Kontekście Rozwoju Regionalnego, Wyd; Dom Organizatora: Torun, Poland, 2019.

18. Jacyna-Gołda, I.; Żak, J.; Gołębiowski, P. Models of traffic flow distribution for various scenarios of the development of proecological transport system. Arch. Transp. 2014, 32, 17-28. [CrossRef]

19. Pernestål, A.; Engholma, A.; Bemlerb, M.; Gidofalvia, G. How Will Digitalization Change Freight Transportation? Future Scenarios for the Digitized Freight Transportation Landscape with Sweden as a Case Study; Project presentation; KTH Royal Institute of Technology: Stockholm, Sweden, 2019.

20. Bäumler, I. Scenario based analysis for intelligent transportation systems for road freight transport. In Proceedings of the 3rd Interdisciplinary Conference on Production, Logistics and Traffic (ICPLT), Darmstadt, Germany, 25-26 September 2017.

21. Blois, H.D.; Martins, R.S. A model of integration among prediction tools: Applied study to road freight transportation. Rev. Adm. 2017, 52, 3-14. [CrossRef]

22. Brand, C.; Anable, J.; Ketsopoulou, I.; Watson, J. Road to zero or road to nowhere? Disrupting transport and energy in a zero carbon world. Energy Policy 2020, 139, 1-26. [CrossRef]

23. European Commission. Communication from the Commission to the European Parliament, the Council, the European Court of Justice, the Court of Auditors, the European Investment Bank, the European Economic and Social Committee and to the Committee of the Regions. A Growth Package for Integrated European Infrastructures; COM (2011) 676 Final Version; European Commission: Brussels, Belgium, 2011.

24. Ricq, C. Handbook on Transfrontier Co-Operation for Local and Regional Authorities in Europe; Council of Europe: Strasbourg, France, 2006.

25. Trans-European Networks-Guidelines. Fact Sheets on the European Union-2020. Available online: https://www.europarl.europa.eu/ftu/pdf/en/FTU_3.5.1.pdf (accessed on 15 May 2020).

26. Roider, O.; Sammer, G.; Riegler, S.; Klementschitz, R.; Bezak, B.; Balko, G. Challenges of border-crossing transport demand surveys-Methodical solutions and experiences with their organization to achieve high quality, an UE-perspective. Transp. Res. 2018, 32, 394-403.

27. Semenov, I. Wybrane aspekty rozwoju transportu i logistyki w regionach przygranicznych. Logistyka 2014, 3, 5645-5646.

28. Meersman, H.; Ehrler, V.C.; Bruckmann, D.; Chen, M.; Francke, J.; Hill, P.; Jackson, C.; Klauenberg, J.; Kurowski, M.; Seidel, S.; et al. Challenges and future research needs towards international freight transport modelling. Case Stud. Transp. Policy 2016, 4, 3-8. [CrossRef]

29. Gamon, W.; Naranjo Gómez, J.M. Main Problems of Railway Cross-Border Transport Between Poland, Germany and Czech Republic. Sustainability 2019, 11, 4900. [CrossRef]

30. Nie, T.; Ye, K. Demystifying the barriers to transport infrastructure project development in fast developing regions: The case of China. Sustainability 2017, 9, 1915. [CrossRef]

31. Ližbetin, J. Methodology for determining the location of intermodal transport terminals for the development of sustainable transport systems: A case study from Slovakia. Sustainability 2019, 11, 1230. [CrossRef]

32. Stoilova, S.; Munier, N.; Kendra, M.; Skrúcaný, T. Multi-criteria evaluation of railway network performance in countries of the TEN-T Orient-East med corridor. Sustainability 2020,12, 1482. [CrossRef]

33. Mun, S.; Nakagawa, S. Pricing and investment of cross-border transport infrastructure. Reg. Sci. Urban Econ. 2010, 40, 228-240. [CrossRef]

34. Kumar, A.; Anbanandam, R. Evaluating the interrelationships among inhibitors to intermodal railroad freight transport in emerging economies: A multi-stakeholder perspective. Transp. Res. Part A Policy Pract. 2020, 132, 559-581. [CrossRef]

35. Medeiros, E. Cross-border cooperation in inner Scandinavia: A territorial impact assessment. Environ. Impact Assess. Rev. 2017, 62, 147-157. [CrossRef]

36. Caris, A.; Macharis, C.; Janssens, G.K. Decision support in intermodal transport: A new research agenda. Comput. Ind. 2013, 64, 105-112. [CrossRef] 
37. Castanho, R.; Loures, L.; Fernández, J.; Pozo, L. Identifying critical factors for success in Cross Border Cooperation (CBC) development projects. Habitat. Int. 2018, 72, 92-99. [CrossRef]

38. Fang, X.; Ji, Z.; Chen, Z.; Chen, W.; Cao, C.; Gan, J. Synergy degree evaluation of container multimodal transport system. Sustainability 2020, 12, 1487. [CrossRef]

39. Ypsilantis, P.; Zuidwijk, R. Collaborative fleet deployment and routing for sustainable transport. Sustainable 2019, 11, 5666. [CrossRef]

40. Barter, P.A. Multiple dimensions in negotiating the cross-border transport links that connect and divide Singapore and Johor, Malaysia. Asia Pac. Viewp. 2006, 47, 287-303. [CrossRef]

41. Kononiuk, A.; Nazarko, J. Scenariusze W Antycypowaniu I Kształtowaniu Przyszłości; Oficyna a Wolters Kluwer Business: Warszawa, Poland, 2014.

42. Brzóska, J. Budowa scenariuszy foresightu kadr nowoczesnej gospodarki. In Foresight Kadr Nowoczesnej Gospodarki; Matusiaka, K.B., Kucińskiego, J., Gryzik, A., Eds.; Polska Agencja Rozwoju Przedsiębiorczości: Warszawa, Poland, 2009; pp. 70-103.

43. Keenan, M.; Miles, I. A Practical Guide to Regional Foresight; Institute for Prospective Technological Studies, FOREN Network: Seville, Spain, 2001.

44. Loveridge, D. Foresight: The Art and Science of Anticipating the Future; Taylor \& Francis: New York, NY, USA, 2009.

45. Godet, M. Forefront: How to be rigorous with scenario planning. Foresight 2000, 2, 5-9. [CrossRef]

46. Kahn, H. Thinking about the Unthinkable; Horizon Press: Hammond, Indiana, 1962.

47. Kahn, H.; Wiener, A.J. The Year 2000: A Framework for Speculation on the Next Thirty-Three Years; The Macmillan: New York, NY, USA, 1967.

48. Schoemaker, P.J.H.; van der Heijden, C.A.J.M. Integrating scenarios into strategic planning at royal Dutch/Shell. Strat Lead. 1992, 20, 41-46. [CrossRef]

49. Bezold, C. Lessons from using scenarios for strategic foresight. Technol. Forecast. Soc. Chang. 2010, 77, 1513-1518. [CrossRef]

50. Duinker, P.N.; Greig, L. Scenario analysis in environmental impact assessment: Improving explorations of the future. Environ. Impact Assess. Rev. 2007, 27, 206-219. [CrossRef]

51. Amer, M.; Daim, T.U.; Jetter, A. A review of scenario planning. Futures 2013, 46, 23-40. [CrossRef]

52. Piirainen, K.; Lindqvist, A. Enhancing business and technology foresight with electronically mediated scenario process. Foresight 2010, 12, 16-37. [CrossRef]

53. Bradfield, R.; Wright, G.; Burta, G.; Cairns, G.; van der Heijdena, K. The origins and evolution of scenario techniques in long range business planning. Futures 2005, 37, 795-812. [CrossRef]

54. Porter, M.E. Competitive Advantage; The Free Press: New York, NY, USA, 1985.

55. Schwartz, P. The Art of the Long View. Planning for the Future in an Uncertain World; Doubleday: New York, NY, USA, 1991.

56. Ringland, G. Scenario Planning: Managing for the Future; John Wiley \& Sons, Inc.: New York, NY, USA, 1998.

57. Van der Heijden, K. Scenarios: The Art of Strategic Conversation; John Wiley: Chichester, UK, 1996.

58. Jarke, M.; Bui, X.T.; Carroll, J.M. Scenario Management: An Interdisciplinary Approach. Requir. Eng. 1998, 3, 155-173. [CrossRef]

59. Fontela, E.; Hingel, A. Scenarios on economic and social cohesion in Europe. Futures 1993, 25, 139-154. [CrossRef]

60. Scholz, R.W.; Tietje, O. Embedded Case Study Methods: Integrating Quantitative and Qualitative Knowledge; Sage: Thousand Oaks, CA, USA, 2002.

61. Martino, J.P. A review of selected recent advances in technological forecasting. Technol. Forecast. Soc. Chang. 2003, 70, 719-733. [CrossRef]

62. De Brabandere, L.; Iny, A. Scenarios and creativity: Thinking in new boxes. Technol. Forecast. Soc. Chang. 2010, 77, 1506-1512. [CrossRef]

63. Curry, A. From foresight to insight: Using scenarios well. J. Futures Stud. 2009, 13, 119-122.

64. Hiltunen, E. Scenarios: Process and outcome. J. Futures Stud. 2009, 13, 151-152.

65. Schoemaker, P.J.H. Multiple scenario development: Its conceptual and behavioral foundation. Strateg. Manag. J. 1993, 14, 193-213. [CrossRef]

66. Barber, M. Questioning scenarios. J. Futures Stud. 2009, 13, 139-146.

67. Wack, P. Scenarios-Uncharted waters ahead. Harv. Bus. Rev. 1985, 63, 72-89. 
68. Schoemaker, P.J.H. Scenario planning-A tool for strategic thinking. MIT Sloan Manag. Rev. 1995, 36, 25-40.

69. Van der Heijden, K. Scenarios, Strategies and the Strategy Process; Nijenrode Research Paper Series (No. 1997-01); Nijenrode University: Breukelen, The Netherlands, 1997.

70. Saritas, O.; Aylen, J. Using scenarios for roadmapping: The case of clean production. Technol. Forecast. Soc. Change 2010, 77, 1061-1075. [CrossRef]

71. Bryant, B.P.; Lempert, R.J. Thinking inside the box: A participatory computer-assisted approach to scenario discovery. Technol. Forecast. Soc. Chang. 2010, 77, 34-49. [CrossRef]

72. Von der Gracht, H.A.; Darkow, I.L. Scenarios for the logistics services industry: A Delphi-based analysis for 2025. Int. J. Prod. Econ. 2010, 127, 46-59. [CrossRef]

73. Lempert, R. Scenarios that illuminate vulnerabilities and robust responses. Clim. Chang. 2013, 117, 627-646. [CrossRef]

74. Parker, A.M.; Srinivasan, S.V.; Lempert, R.J.; Berry, S.H. Evaluating simulation-derived scenarios for effective decision support. Technol. Forecast. Soc. Chang. 2015, 91, 64-77. [CrossRef]

75. Alipour, M.; Hafezi, R.; Amer, M.; Akhavan, A.N. A new hybrid fuzzy cognitive map-based scenario planning approach for Iran's oil production pathways in the postesanction period. Energy 2017, 135, 851-864. [CrossRef]

76. Proskuryakova, L.N.; Saritas, O.; Sivaev, S. Global water trends and future scenarios for sustainable development: The case of Russia. J. Clean. Prod. 2018, 170, 867-879. [CrossRef]

77. Van der Heijden, K. Scenarios: The Art of Strategic Conversation, 2nd ed.; John Wiley \& Sons: Hoboken, NJ, USA, 2005.

78. Bishop, P.; Hines, A.; Collins, T. The current state of scenario development: An overview of techniques. Foresight 2007, 9, 5-25. [CrossRef]

79. Phadnis, S.; Caplice, C.; Sheffi, Y.; Singh, M. Effect of scenario planning on field experts' judgment of long-range investment decisions. Strateg. Manag. J. 2015, 36, 1401-1411. [CrossRef]

80. Ramirez, R.; Churchhouse, S.; Palermo, A.; Hoffmann, J. Using scenario planning to reshape strategy. MIT Sloan Manag. Rev. 2017, 58, 31-37.

81. Thomas, C.; Chermack, T. Using Scenario Planning to Supplement Supply Chain Risk Assessments. In Revisiting Supply Chain Risk; Zsidisin, G.A., Henke, M., Eds.; Springer: Berlin/Heidelberg, Germany, 2019; pp. 37-51.

82. Vecchiato, R. Scenario planning, cognition, and strategic investment decisions in a turbulent environment. Long Range Plan. 2019, 52, 101865. [CrossRef]

83. Marcial, E.L.; Costa, A.J.L. O Uso de Cenários Prospectivos na Estratégia Empresarial:Evidência Especulativa ou Inteligência Competitiva? Eletrônicos Enanpad: Campinas, Brazil, 2012.

84. Marcial, E.L.; Grumbach, R.J.S. Cenários Prospectivos: Como Construir um Futuro Melhor, 5th ed.; FGV: Rio de Janeiro, Brazil, 2012.

85. Wright, L.; Fulton, L. Climate change mitigation and transport in developing nations. Transp. Rev. 2005, 25, 691-717. [CrossRef]

86. Oei, P.; Mendelevitch, R. European Scenarios of $\mathrm{Co}_{2}$ infrastructure investment. Energy J. 2016, 37, 171-192. [CrossRef]

87. Yang, L.; Wang, Y.; Lian, Y.; Han, S. Factors and scenario analysis of transport carbon didoxide emissions in rapidly-Developing cities. Transp. Res. Part D Transp. Environ. 2020, 80, 102252. [CrossRef]

88. Knop, L.; Olko, S. Characteristics of clusters in logistics sector in Poland against the background of other clusters. In Conference Proceedings, Proceedings of the 8th Carpathian Logistics Congress. CLC 2018. Logistics, Distribution, Transport \& Management, Prague, Czech Republic, 3-5 November 2018; Tanger: Ostrava, Czech Republic, 2019; pp. 318-323.

89. Johansen, I. Scenario modelling with morphological analysis. Technol. Forecast. Soc. Chang. 2018, 126, 116-125. [CrossRef]

90. Bäumler, I.; Kotzab, H. Scenario-based development of intelligent transportation systems for road freight transport in Germany. Urban. Freight Transp. Syst. 2020, 183-202. [CrossRef]

91. Ruciński, A.; Konrad, M. Metoda scenariuszowa w badaniach rozwoju transportu lotniczego do roku 2030. Zeszyty Naukowe Uniwersytetu Gdańskiego. Ekon. Transp. I Logistyka 2014, 52, 73-95.

92. Blois, H.; Suoza, J. Cenarios prospectivos e a dinamica de sistemas: Proposta de um modelo para o setor calcadista. Rev. Adm. Empresas 2008, 48, 35-45. [CrossRef] 
93. Reggiani, A.; Cattaneo, S.; Janicp, M.; Nijkamp, P. Freight Transport in Europe: Policy Issues and Future Scenarios on Trans-Border Alpine Connections. IATSS Res. 2000, 24, 48-59. [CrossRef]

94. Hines, A.; Bishop, P. Thinking about the Future: Guidelines for Strategic Foresight; Social Technologies LLC: Washington, DC, USA, 2006.

95. Kononiuk, A. Metoda scenariuszowa w antycypowaniu przyszłości. Organ. I Kier. 2012, 2, $33-48$.

96. Godet, M. Manual de Prospectiva Estratégica: Da Antecipação à Acção; Don Quixote: Lisbon, Portugal, 1993; Translation from J. Freitas e Silva.

97. Ryszko, A. Proactive environmental strategy, technological eco-innovation and firm performance-Case of Poland. Sustainability 2016, 8, 156. [CrossRef]

98. Dohn, K.; Przybyska, E.; Żebrucki, Z. Evaluation of the cross-border area regions potential for the development of intermodal transport. Res. Logist. Prod. 2019, 9, 15-29.

99. Knop, L.; Kramarz, M. Attractiveness of the region in connection with intermodal transport development. In Sustainable Logistics and Production in Industry 4.0. New Opportunities and Challenges; Grzybowska, K., Awasthi, A., Sawhney, R., Eds.; Springer: Cham, Switzerland, 2020; pp. 197-217.

100. Godet, M.; Durance, P. La Prospective Stratégique: Pour les Entreprises et les Territoires; Dunod: Paris, France, 2008.

101. Hong, S.-J.; Kim, T. Determining the Priority of Transport Policies: With a Special Focus on the Data, Envelopment Analysis Using Ranked Voting Data. Transp. Policy Stud. Rev. 2009, 12, 21-28.

102. Noguchi, H.; Ogawa, M.; Ishii, H. The appropriate total ranking method using DEA for multiple categorized purposes. J. Comput. Appl. Math. 2002, 146, 155-166. [CrossRef]

(C) 2020 by the authors. Licensee MDPI, Basel, Switzerland. This article is an open access article distributed under the terms and conditions of the Creative Commons Attribution (CC BY) license (http://creativecommons.org/licenses/by/4.0/). 